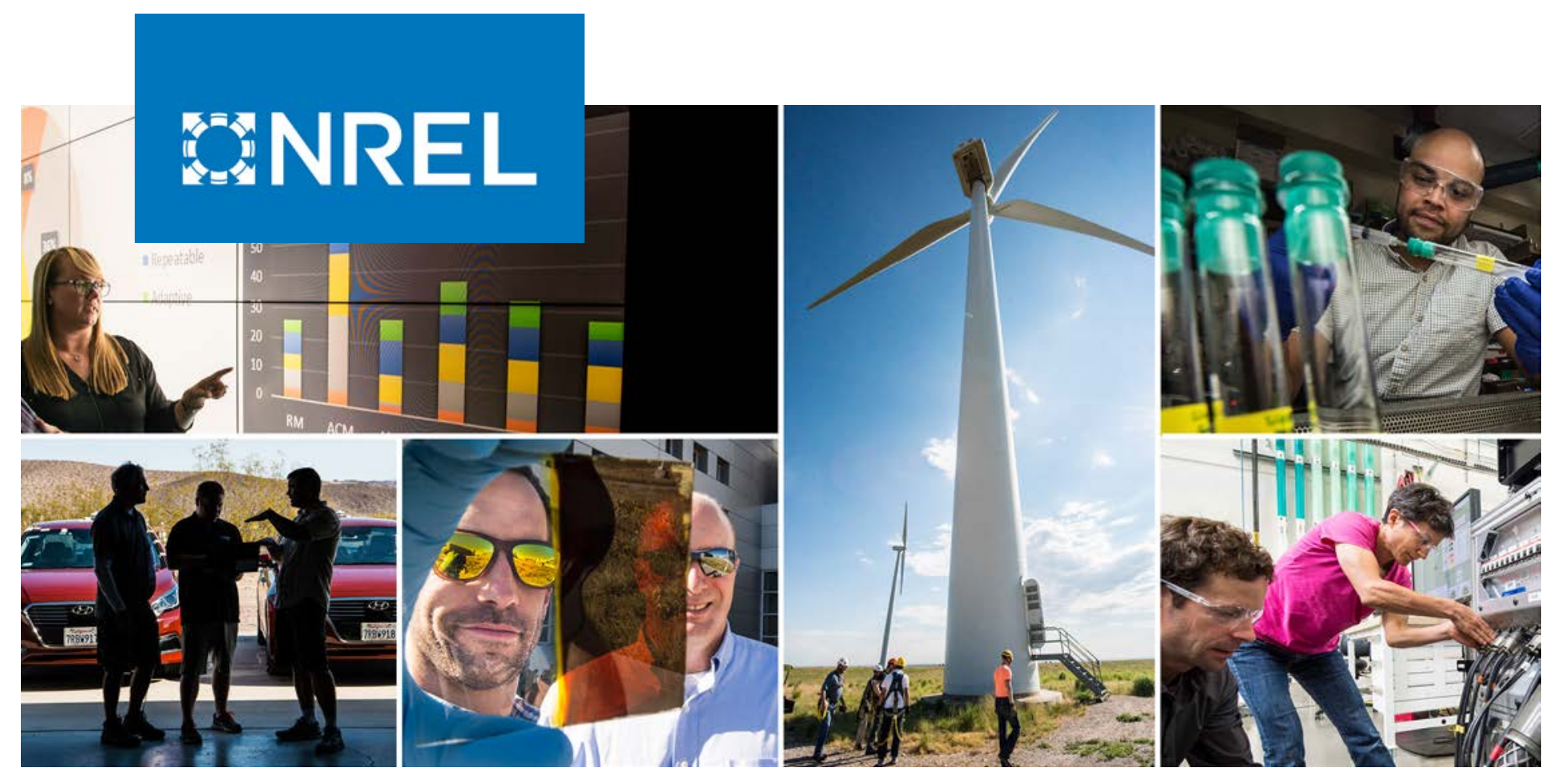

\title{
State and Local Policy Impacts on the Residential Solar PV Installation Industry
}

Eric O'Shaughnessy

National Renewable Energy Laboratory

NREL is a national laboratory of the U.S. Department of Energy Office of Energy Efficiency \& Renewable Energy

Operated by the Alliance for Sustainable Energy, LLC

This report is available at no cost from the National Renewable Energy Laboratory (NREL) at www.nrel.gov/publications.

\section{Technical Report}

NREL/TP-6A20-72149

January 2019 


\title{
FNREL
}

\section{State and Local Policy Impacts on the Residential Solar PV Installation Industry}

\author{
Eric O'Shaughnessy
}

National Renewable Energy Laboratory

\section{Suggested Citation}

O'Shaughnessy, Eric. 2019. State and Local Policy Impacts on the Residential Solar PV Installation Industry. Golden, CO: National Renewable Energy Laboratory. NREL/TP-6A20-72149. https://www.nrel.gov/docs/fy19osti/72149.pdf.

NREL is a national laboratory of the U.S. Department of Energy Office of Energy Efficiency \& Renewable Energy Operated by the Alliance for Sustainable Energy, LLC

This report is available at no cost from the National Renewable Energy Laboratory (NREL) at www.nrel.gov/publications.

Contract No. DE-AC36-08GO28308
Technical Report NREL/TP-6A20-72149 January 2019

National Renewable Energy Laboratory 15013 Denver West Parkway Golden, CO 80401 303-275-3000 • www.nrel.gov 


\section{NOTICE}

This work was authored by the National Renewable Energy Laboratory, operated by Alliance for Sustainable Energy, LLC, for the U.S. Department of Energy (DOE) under Contract No. DE-AC36-08GO28308. Funding provided by U.S. Department of Energy Office of Energy Efficiency and Renewable Energy Solar Energy Technologies Office. The views expressed in the article do not necessarily represent the views of the DOE or the U.S. Government.

This report is available at no cost from the National Renewable Energy Laboratory (NREL) at www.nrel.gov/publications.

U.S. Department of Energy (DOE) reports produced after 1991 and a growing number of pre-1991 documents are available free via www.OSTI.gov.

Cover Photos by Dennis Schroeder: (clockwise, left to right) NREL 51934, NREL 45897, NREL 42160, NREL 45891, NREL 48097, NREL 46526.

NREL prints on paper that contains recycled content. 


\section{Acknowledgments}

This work was supported by the Solar Energy Technologies Office within the U.S. Department of Energy's Office of Energy Efficiency and Renewable Energy. The author would like to thank Justin Baca (Solar Energy Industries Association [SEIA]), Ilya Chernyakhovskiy (NREL), Felipe Flores-Golfin (University of Pennsylvania), Sean Gallagher (SEIA), Kevin Lucas (SEIA) and Greg Nemet (University of Wisconsin-Madison) for their thoughtful review of this work. The author would also like to thank Mike Meshek (NREL) and Jarett Zuboy (consultant) for editorial support. 


\section{Executive Summary}

Hundreds of state and local policies have contributed to the expansion of residential solar photovoltaics (PV) in the United States. This study explored the effects of such policies on local PV installation industries using a rich data set of residential PV systems installed from 2010 to 2016. The study results show that state and local policies affect the number of installers that compete in local PV markets, the relative sizes of those installers, and the market shares of highvolume national-scale installers. Understanding these effects could improve PV policy analysis and yield insights into how to achieve multiple PV policy objectives.

In the study, an econometric model was developed to test the effects of policies on local PV installation industries. The model was used to test the effects of five policies (Table ES-1) on three industry variables: the number of installers, the distribution of market shares among installers, and the market shares of national-scale installers. The modeling results were consistent with the expected outcomes for the effects of bill savings and policies that allow third-party ownership (TPO). The model produced the unexpected result that subsidies are associated with markets with fewer installers. The model produced inconclusive results for the effects of ongoing incentives and interconnection policies.

Table ES-1. Results Compared to Hypotheses

\begin{tabular}{lll}
\hline Policy & Hypothesis & Result \\
\hline Bill savings & $\begin{array}{l}\text { Higher bill savings induce market entry, result in } \\
\text { markets with more installers }\end{array}$ & Supported \\
Subsidies & $\begin{array}{l}\text { Higher subsidies induce market entry, result in } \\
\text { markets with more installers }\end{array}$ & Rejected \\
Ongoing incentives & $\begin{array}{l}\text { Higher ongoing incentives induce market entry, } \\
\text { result in markets with more installers }\end{array}$ & Inconclusive \\
\hline Interconnection burden & $\begin{array}{l}\text { Higher interconnection burden reduces market } \\
\text { entry, results in markets with fewer installers }\end{array}$ & Inconclusive \\
TPO & $\begin{array}{l}\text { More TPO penetration increases returns to } \\
\text { scale, results in shift of market shares toward } \\
\text { higher-volume installers (higher Herfindahl- } \\
\text { Hirschman Index) }\end{array}$ & Supported \\
\hline
\end{tabular}

Several robustness checks were provided to address potential model limitations. In particular, it is possible that certain industry characteristics affect certain policies, which would violate key assumptions needed to ensure valid econometric results. To control for potential reverse causality, a special model was developed testing policy effects within a narrow geographic corridor around the border of two major utilities in California. The econometric model, the geographic corridor model, and other robustness checks yielded three key findings:

- Rate structures that yield higher customer bill savings are associated with markets with more installers, whereas subsidies are associated with markets with fewer installers: high volumetric electricity rates (dollars per kilowatt-hour) and favorable net-metering policies increase the potential bill savings due to PV adoption. The results of this study suggest that this increased value induces more installers to enter markets where 
customers enjoy higher bill savings: a $\$ 1 / \mathrm{W}$ increase in bill savings is associated with an $80 \%$ increase in the number of competing installers, all else being equal. In contrast, subsidies such as upfront rebates and tax credits are associated with markets with fewer installers, possibly because installers focus on increasing market share in markets where $\mathrm{PV}$ is more heavily subsidized, or because some installers are able to achieve higher market shares in subsidized PV markets.

- Subsidies and ongoing incentives are associated with markets where national-scale installers hold less market share: A $\$ 1 / \mathrm{W}$ increase in upfront subsidies is associated with about a 10 percentage point reduction in the local market share of national-scale installers. Subsidy programs may favor regional and local installers for at least two reasons. First, upfront subsidies such as rebates incentivize customers to purchase PV systems rather than procure PV through a third-party ownership (TPO) model such as a lease. Given that local installers tend to offer customer-owned systems while nationalscale installers have historically tended to offer TPO, upfront subsidies tend to increase the value of local installer products relative to national-scale installer products. Second, local installers may better understand the nuances of local subsidy programs or enjoy other local competitive advantages, such as being on a list of qualified local installers on a subsidy program website.

- Higher levels of TPO are associated with markets where national-scale installers hold more market share: TPO systems tend to be installed by high-volume installers. As a result, policies that support TPO installation tend to shift market shares from low- to high-volume installers and to increase the market share of national-scale installers.

The policy implications of these results depend on local policy objectives. For instance, the results suggest that subsidy programs support local and regional installers and may therefore support local PV business development and economic benefits. At the same time, national-scale installers are often better positioned to offer customer financing products such as TPO and solar loans. Access to customer financing has historically increased PV adoption, particularly among cash-constrained customers. Policymakers may seek to implement optimal policy mixes that balance multiple policy objectives, such as supporting local installers while also promoting customer access to PV financing products. 


\section{Table of Contents}

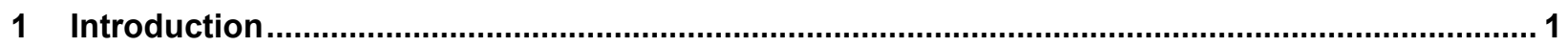

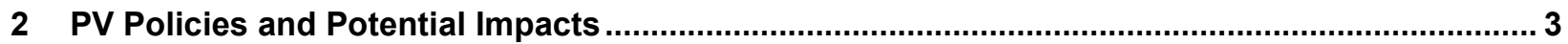

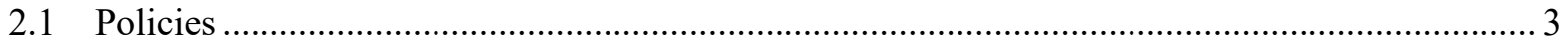

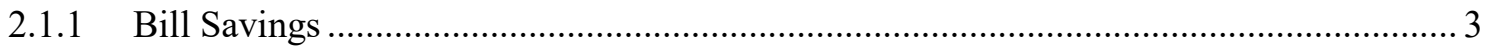

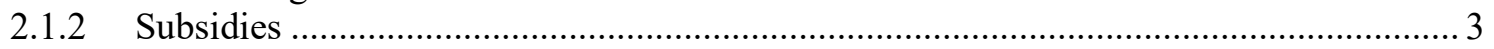

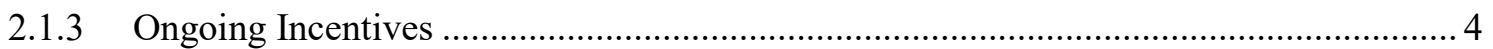

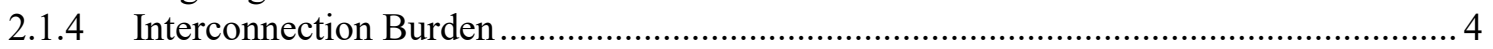

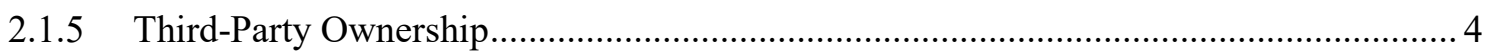

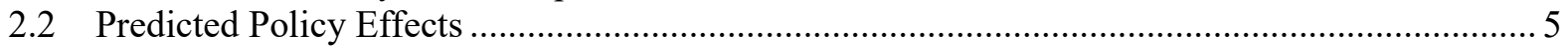

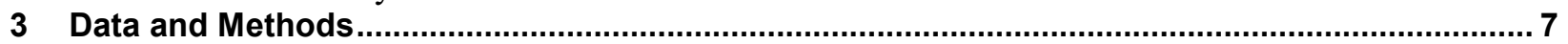

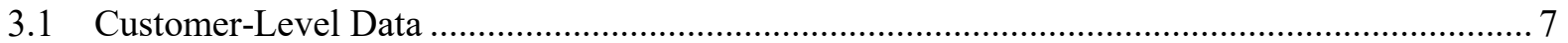

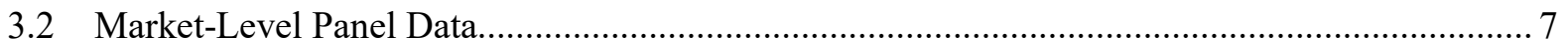

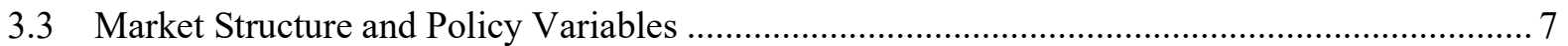

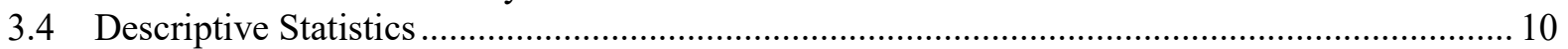

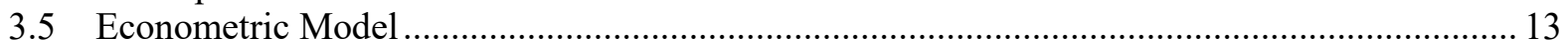

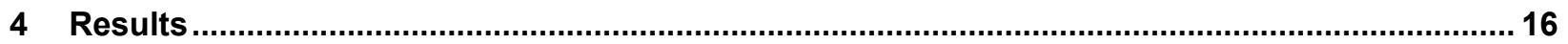

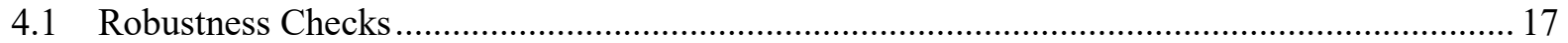

4.1.1 Alternative Market Definition ..................................................................... 17

4.1.2 Geographic Discontinuity .......................................................................... 18

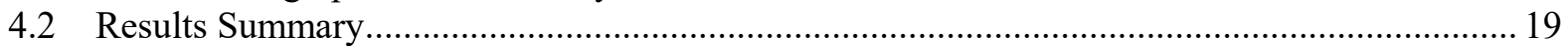

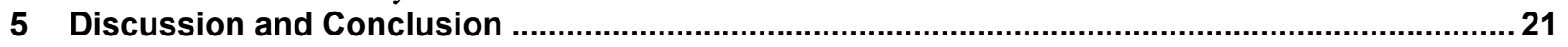

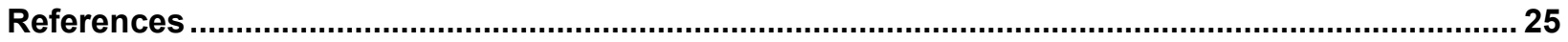

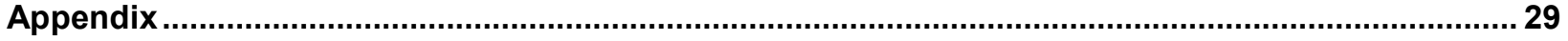




\section{List of Figures}

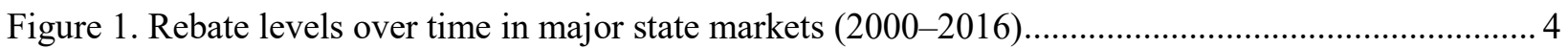

Figure 2. Summary of predicted effects of policies on local PV installation industries ............................. 6

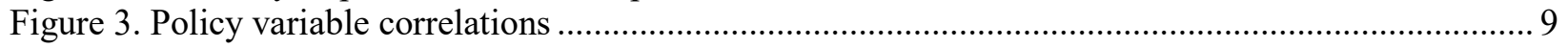

Figure 4. Distribution of HHI measurements (left) and HHI by year (right) ........................................ 10

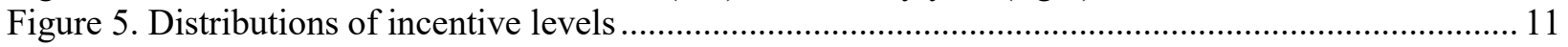

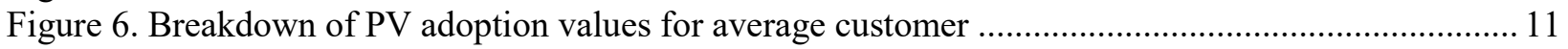

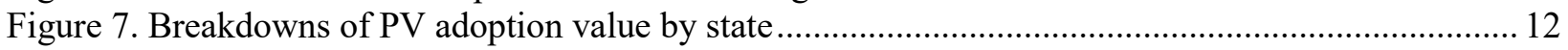

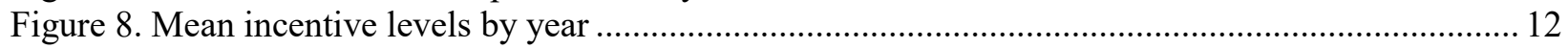

Figure 9. Distribution of TPO penetrations (left) and TPO penetration over time (right) ........................ 13

Figure 10. Study area in 20-mile corridor around PG\&E/SCE border (right) and subsidy levels over time on either side of the border (left) ...................................................................................... 15

Figure 11. Summary of effects of policies on PV market structure variables ........................................ 19

Figure 12. Correlation between percentage of installers implementing a market share strategy and the sum

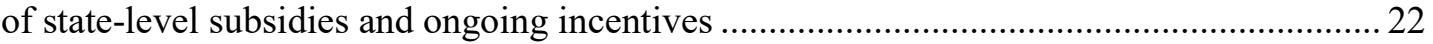

\section{List of Tables}

Table ES-1. Results Compared to Hypotheses ......................................................................................... iv

Table 1. Summary Statistics for Market Structure and Policy Variables.................................................. 9

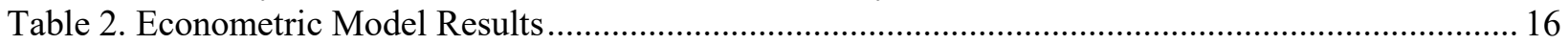

Table 3. Policy Variable Coefficients, Markets = Counties................................................................. 18

Table 4. Regression Results Limited to Corridor at PG\&E/SCE Border................................................ 18

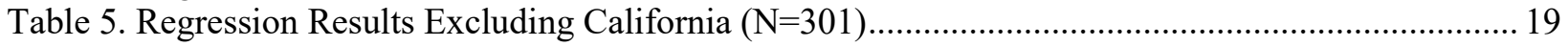

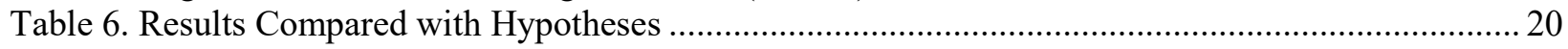

Table A-1. Summary Statistics for Control Variables ........................................................................... 31 


\section{Introduction}

Hundreds of state and local policies have contributed to the expansion of residential solar photovoltaics (PV) in the United States. Policies relevant to PV include electric utility rate structures, ${ }^{1}$ upfront subsidies, ongoing incentives, interconnection requirements, and rules related to customer financing. Research to date has explored how such policies affect PV adoption (Sarzynski, Larrieu, and Shrimali 2012; Steward and Doris 2012; Hughes and Podolefsky 2015; Borenstein 2017; Crago and Chernyakhovskiy 2017), prices (Gillingham et al. 2016; Nemet et al. 2017; Pless and van Benthem 2017; Dong, Wiser, and Rai 2018), and manufacturing (Chung, Horowitz, and Kurup 2016; Lacasa and Shubbak 2018; Zhi et al. 2014; Quitzow 2015). This study fills a remaining research gap by exploring the effects of state and local policies on the residential PV installation industry.

The effects of policy on the PV installation industry are of particular interest owing to the localized nature of PV installation. Unlike PV manufacturers who sell their products globally, installers must have a physical presence in their customers' areas. Furthermore, PV installation is characterized by relatively low returns to scale. Whereas a PV module manufacturer may need to produce millions of units per year to remain profitable, a local electrician or construction contractor can profitably install at a relatively small scale. Indeed, the vast majority of PV installers complete one or fewer systems per month, with only a small number of installers completing tens or hundreds of systems per month (O'Shaughnessy 2018b). Because of these characteristics, the residential $\mathrm{PV}$ installation industry is more accurately characterized as a network of local industries (O'Shaughnessy, Nemet, and Darghouth 2018). This study asks, what are the effects of state and local policies on these local installation industries? And, what role could variations in state and local policies play in creating differences among local industries?

Understanding the effects of policy on installation industries has implications for PV policy analysis. Policy analysts must account for direct and indirect policy effects when projecting the impacts of $\mathrm{PV}$ policies. For instance, an upfront rebate of $\$ 1$ per watt $(\$ / \mathrm{W})$ has a direct effect of reducing post-incentive PV prices. Analysts may use this direct effect to estimate the effects of the rebate on PV adoption levels. However, rebates may also have indirect effects on local installation industries. Changes in a local installation industry may ultimately affect prices and PV adoption levels, so analysis based only on the direct effects of the rebate would yield biased results. This report provides a first step toward understanding and quantifying these indirect effects to inform future PV policy analyses.

The results of this study may also inform how policymakers can design optimal policy mixes to achieve multiple PV supply- and demand-side objectives. Policies that support local installers may support local PV business development and yield local economic benefits. At the same time, national-scale installers are more likely to offer innovative customer financing products such as leases and solar loans (Litvak 2017), which may increase PV adoption, particularly among cashconstrained customers (Drury et al. 2012; Sigrin, Pless, and Drury 2015). This report shows how

\footnotetext{
${ }^{1}$ Electric utility rates are policies in two regards. First, rates must be approved by state-level regulatory bodies and are thus indirectly controlled by state policymakers. Second, utility decisions are ultimately policy decisions and can be interpreted as such, particularly in the case of locally administered municipal utilities.
} 
policies such as utility rate structures and subsidies differentially affect the local- versus national-scale composition of local PV installation industries.

The report is structured as follows. Section 2 summarizes five state and local policies that affect residential PV markets in the United States, and it predicts the impacts of these policies on local installation industries. Section 3 describes the data and methods used to test the effects of the five policies on local installation industries. Section 4 presents the results, and Section 5 concludes with a discussion of key findings and areas for future research. 


\section{PV Policies and Potential Impacts}

This section summarizes five policies that affect residential PV markets. The five policies are not a comprehensive group of all policies that may affect PV markets. The selection is partially data driven: the five policies are relatively easy to quantify, allowing for robust tests of their effects on PV installation industries. In particular, local codes (e.g., zoning and building codes) are excluded from the analysis, as they vary across jurisdictions in numerous ways that may be difficult to quantify. The discussion in this section may provide insights into the expected impacts of local codes on PV installation industries, and empirical testing of these effects may be an area for future research.

\subsection{Policies}

The five policies analyzed include bill savings, subsidies, ongoing incentives, interconnection burden, and third-party ownership (TPO).

\subsubsection{Bill Savings}

Residential PV adopters save money by reducing the volumetric (dollars per kilowatt-hour [\$/kWh]) portion of their electricity bills (Darghouth, Wiser, and Barbose 2016; Borenstein 2017). Adopters may further reduce their electricity bills by earning credits for excess PV output delivered to the grid (i.e., net metering). Volumetric rates and net-metering rates are determined by regulator-approved rate structures, so customer bill savings from PV adoption are a function of both state and utility policies. Thirty-eight states and Washington, D.C., currently require utilities to offer net-metering programs (Proudlove et al. 2018b). The amount of the net-metering credit varies, though most residential PV customers have historically received credits equal to the retail electricity rate.

\subsubsection{Subsidies}

The U.S. government as well as most states and many sub-state jurisdictions offer upfront subsidies for PV adoption (NC CETC 2018). ${ }^{2}$ State and local subsidies include rebates and state investment tax credits (ITCs). PV subsidy programs are generally designed so that the value of the subsidy declines over time as prices decline (Figure 1).

\footnotetext{
${ }^{2}$ The federal investment tax credit (ITC) is equal to $30 \%$ of the installed cost of PV systems, but it is excluded from the analysis because it does not vary across markets.
} 


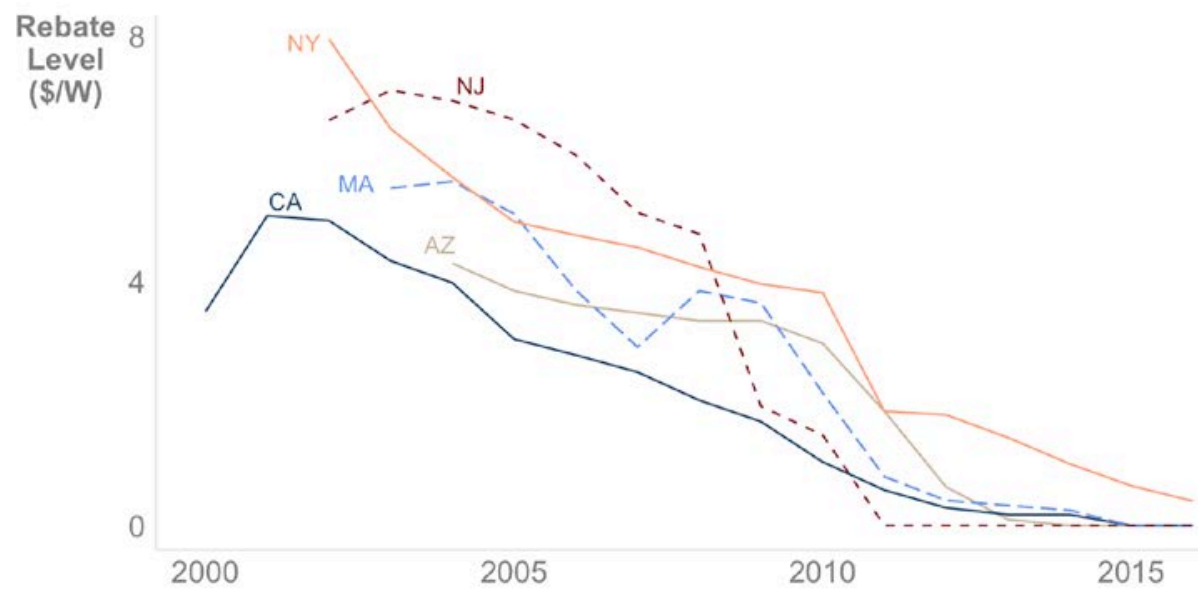

Figure 1. Rebate levels over time in major state markets (2000-2016)

Based on data from Barbose and Darghouth 2017

\subsubsection{Ongoing Incentives}

In addition to or in lieu of subsidies, some jurisdictions offer ongoing incentives based on PV output. Production-based incentives provide a guaranteed dollar value per kilowatt-hour produced, whereas solar renewable energy certificates (SRECs) - tradable instruments that encompass the clean energy attributes of one megawatt-hour (MWh) of PV output-can be sold to provide ongoing revenue. SREC markets have emerged in states with targets for PV generation, where electricity providers must procure specified amounts of SRECs to meet the targets. Residential PV customers in such states can sell SRECs to these regulated entities, though an installer or regulator generally handles this process.

\subsubsection{Interconnection Burden}

Most U.S. PV systems are interconnected to the grid. Grid interconnection entails various compliance procedures and permits. The full interconnection process takes about 50 days for U.S. residential PV systems, but it varies significantly across states and local jurisdictions (Ardani et al. 2015). Differences in local interconnection and other permitting requirements can significantly affect installation times and costs (Dong and Wiser 2013; Burkhardt et al. 2015).

\subsubsection{Third-Party Ownership}

Beginning in the mid-2000s, some PV companies began to install TPO systems on residential rooftops. In the TPO model, retail electricity customers make ongoing lease (\$/month) or power purchase $(\$ / \mathrm{kWh})$ payments to the system owner for the rights to the system's output, which is similar to how automobiles are leased. TPO markets were initially constrained by traditional electricity regulations (Beck and Martinot 1994; Kollins, Speer, and Cory 2010; Drury et al. 2012), which only allowed regulated utilities or licensed electricity providers to sell electricity to retail customers. Such regulations apply to TPO systems unless interpreted otherwise by public utility commissions or other state regulators. 
Twenty-six states and Washington, D.C., have interpreted or amended regulations to explicitly allow TPO systems, nine states explicitly prohibit or restrict TPO systems, and the remainder have no explicit TPO policy (Proudlove et al. 2018b). TPO-allowing regulations generally stipulate that third-party system owners are exempt from utility or electricity provider regulation (NC CETC 2018). These reforms to accommodate TPO led to a significant increase in TPO system deployment and increased PV deployment overall (Drury et al. 2012). At its peak in 2014, TPO systems comprised more than $70 \%$ of the residential PV market (Litvak 2017). The TPO market share has since fallen to around half of all residential PV systems, owing to falling PV prices and the increasing attractiveness of customer ownership (Litvak 2017).

\subsection{Predicted Policy Effects}

None of the five policies examined in this study is designed explicitly to affect local PV installation industries. Rather, these policies may have indirect effects on local industries by affecting the individual decisions of installers to enter or exit markets, as well as the competitive dynamics between installers that determine their market shares.

Bill savings, subsidies, and ongoing incentives all increase the value of PV adoption and should, all else being equal, increase customer demand for PV systems. Economic theory suggests higher demand should attract more installers to "enter" PV markets (Burrows 1979; Conrad and Wang 1993; Laincz 2005; Dunne et al. 2013; Currier 2015). Markets with higher bill savings, subsidies, and ongoing incentives are therefore expected to yield installation industries with more competing installers, all else being equal.

Interconnection burdens increase installer costs and reduce installer profitability, which should theoretically deter installers from entering these markets (Burrows 1979; Markusen, Morey, and Olewiler 1993; Katsoulacos and Xepapadeas 1995). Markets with burdensome interconnection requirements are therefore expected to yield installation industries with fewer competing installers, all else being equal.

TPO policies are expected to yield a shift of market shares from low- to high-volume installers, owing to the higher returns to scale involved in the TPO model. In TPO transactions, the thirdparty owner is generally a tax-equity investor that buys the system to realize the tax benefits from the federal ITC and other applicable tax incentives. The cost of tax equity is equal to the fee that the tax-equity investor charges to monetize the tax benefits on behalf of the customer and installer. In general, tax equity is only cost-effective when installers can aggregate asset bases (PV systems) on the order of tens of millions of dollars (Schmalensee et al. 2015). As a result, only high-volume installers have access to low-cost tax equity, such that market shares tend to be skewed toward high-volume installers in TPO markets (O'Shaughnessy 2018b).

Figure 2 summarizes the predicted effects of the PV policies on local PV installation industries. The three financial incentives (bill savings, subsidies, ongoing incentives) are all predicted to increase the number of installers, higher interconnection burdens are predicted to reduce the number of installers, and TPO-enabling policies are expected to redistribute market shares toward higher-volume installers. The remainder of this report empirically tests these effects. 


Bill savings,
subsidies,
ongoing incentives
$\begin{gathered}\text { Increase profitability, } \\ \text { induce market entry, } \\ \text { more installers }\end{gathered}$

Figure 2. Summary of predicted effects of policies on local PV installation industries 


\section{Data and Methods}

This section describes the data and methods used to test the effects of policy on local PV installation industries. A study period of 2010 to 2016 is used to ensure the results reflect recent trends in PV markets while providing temporal variation sufficient to observe these trends.

\subsection{Customer-Level Data}

Customer-level data were based on Lawrence Berkeley National Laboratory's Tracking the Sun (TTS) 10 data set (Barbose and Darghouth 2017). TTS aggregates data from more than 60 state and utility incentive programs. The full TTS data set covers more than $80 \%$ of the U.S. PV market, making it the most comprehensive U.S. PV data set. To ensure all observations represent residential PV systems, all observations that self-reported as nonresidential were dropped, as were systems larger than $15 \mathrm{~kW}$. Observations without a valid value for ZIP code were dropped, because ZIP codes are required for the market definition used in the study. Self-installed systems and systems without a valid installer name were dropped. Systems without a valid utility name or utility rate data from the U.S. Utility Rate Database (URDB) ${ }^{3}$ were dropped. Finally, observations having reported ongoing incentives with net present values (NPVs) greater than $\$ 10 / \mathrm{W}$ were dropped as likely data-entry errors (which applied to about $0.02 \%$ of the data).

\subsection{Market-Level Panel Data}

Panel data refer to data sets in which the same unit of analysis (e.g., a market) has multiple observations, which typically correspond to multiple observations over time. Panel data were considered "balanced" if each unit of analysis has an observation for each unit of time. Balanced panel data have several methodological advantages that allow researchers to control for unobserved factors through fixed effects (Kennedy 2008). In this study, the customer-level TTS data were used to construct a market-level balanced panel data set.

The first task in generating the panel data is to define markets. O'Shaughnessy et al. (2018) discuss the importance of valid market definition in the context of PV installation. That study shows how markets based on jurisdictional proxies such as county lines can yield biased results, generally by overestimating market size. The authors develop an alternative approach based on the spatial distribution of competing installers. Put simply, the approach is an algorithm that draws market lines between dissimilar groups of localized installers. Applying this algorithm to the customer-level data set resulted in 1,416 unique markets. By way of comparison, there are about 700 counties and 10,000 ZIP codes in the TTS data set, so the installer-based market definition results in markets sized somewhere between counties and ZIP codes. To ensure the panel data were balanced, markets without at least one system installed per year from 2010 to 2016 were dropped. The final data set comprised 534 unique markets based on 572,414 residential PV systems installed from 2010 to 2016 in 11 states.

\subsection{Market Structure and Policy Variables}

Industries are commonly described in terms of their market structure, a broad term encompassing industrial characteristics such as the number and relative sizes of an industry's firms (Tirole

\footnotetext{
3 “Utility Rate Database,” OpenEI, https://openei.org/wiki/Utility_Rate_Database.
} 
1988). The simplest component of PV market structure is the number of installers. Another common market structure metric is the Herfindahl-Hirschman Index (HHI):

$$
H H I=\sum_{i=1}^{N} s_{i}^{2}=\frac{1}{N}+N \sigma_{s}^{2}
$$

Where $N$ is the number of competitors in a market, $s_{i}$ is the market share of the $i$ th firm, and $\sigma_{s}^{2}$ is the variance of market shares. HHI is a measure of market concentration: the degree to which an industry's market shares are skewed toward its high-volume firms. As shown in Equation (1), HHI simultaneously measures market concentration as an inverse function of the number of firms and an increasing function of the variance of market shares. A low HHI indicates market shares are relatively evenly distributed across many low-volume installers, while a high HHI indicates market shares are primarily held by a few, relatively high-volume installers.

An additional market structure characteristic of interest is the relative market shares of nationalscale versus regional and local installers. Though the vast majority of PV installers are local businesses, a few companies have grown to serve customers around the country. These nationalscale installers are generally more capable of offering TPO products, and they are increasingly offering to finance customer-owned systems through solar loan products (Litvak 2017). For the purposes of this study, a national-scale installer is defined as an installer that is active in all five of the largest state markets: Arizona, California, Massachusetts, New Jersey, and New York. Only five installers meet this criterion, yet these installers account for about $39 \%$ of the systems installed in the data set. A national-scale installer market share variable - defined as the percentage of systems installed in a market in a given year by national-scale installerswas tested.

Policy variables are generated for each of the five policies discussed in Section 2. Bill savings and ongoing incentives are converted to NPV, and all three financial incentives are normalized by system size $(\$ / \mathrm{W})$ to allow for easy comparison of effects. Customer-level financial incentives are converted to market-level incentives by averaging the value of incentives for all customers over each market by year. The TPO penetration variable ranges from 0 (no TPO in that market in that year) to 1 (100\% of systems used TPO in that market in that year). The TPO variable is a continuous variable representing TPO penetration rather than a policy indicator variable. About half of state-level TPO policies are ambiguous, and several states that allow TPO have implemented various system size and customer class restrictions (NC CETC 2018). The TPO penetration variable should reflect the effects of TPO policies in practice. That is, states with more favorable TPO policies should have higher TPO penetrations than do states with less favorable TPO policies, all else being equal. Nonetheless, the TPO penetration variable is an imperfect proxy for TPO policy. Excluding the TPO variable from the model does not change the signs or statistical significance of the other policy variables. An interconnection burden score variable is generated based on a qualitative classification system from Freeing the Grid (2018). All markets are assigned a burden score ranging from 1 to 3, with 1 representing the lowest burden and 3 representing the highest burden. Where markets cross state borders, the marketlevel interconnection score is the weighted average of state-level interconnection scores according to the number of customers. The interconnection score is treated as a categorical variable, meaning a score of 3 is not assumed to mean 3 times the burden of a score of 1 . Table 1 
provides summary statistics for the market structure and policy variables. Methods and assumptions used to generate the policy variables are provided in the appendix.

Table 1. Summary Statistics for Market Structure and Policy Variables

\begin{tabular}{lccrrc}
\hline \multicolumn{1}{c}{ Variable } & Mean & SD & Min & Max & Source \\
\hline Dependent market structure variables & & & & & \\
Number of installers $(\mathrm{N})$ & 23.1 & 27.1 & 1 & 378 & Calculated \\
HHI & 0.25 & 0.21 & 0.03 & 1 & Calculated \\
National-scale market share (\%) & 26.1 & 24.1 & 0 & 100 & Calculated \\
& & & & & \\
Policy variables & & & & & \\
Bill savings $(\$ / \mathrm{W})$ & 3.43 & 1.37 & 1.11 & 5.61 & URDB/DSIRE \\
Subsidies $(\$ / \mathrm{W})$ & 0.72 & 0.80 & 0.00 & 6.93 & TTS \\
Ongoing incentives $(\$ / W)$ & 0.67 & 1.17 & 0.00 & 2.85 & TTS \\
Interconnection burden (1-3) & 1.68 & 0.64 & 1 & 3 & FTG \\
TPO & 0.48 & 0.31 & 0 & 1 & Calculated \\
\hline
\end{tabular}

URDB = Utility Rate Database; DSIRE = Database of State Incentives for Renewables and Efficiency; FTG $=$ Freeing the Grid

The five policy variables are not necessarily independent of one another (Figure 3). Bill savings levels inversely correlate with subsidies and ongoing incentives, which may indicate policymakers implement higher incentives in areas with lower private incentives to adopt PV. Upfront subsidy levels inversely correlate with ongoing incentives, suggesting these two incentives are substitutes rather than complementary policies. Markets with higher subsidies tend to exhibit lower TPO penetration levels, while markets with larger bill savings and ongoing incentives tend to exhibit higher TPO penetration levels. These correlations suggest incentive policies may affect customer choices between system ownership and TPO. System ownership may be more attractive for customers who are eligible for larger upfront subsidies. In contrast, TPO products that can offer immediate savings may be more attractive to customers in areas with low upfront subsidies.

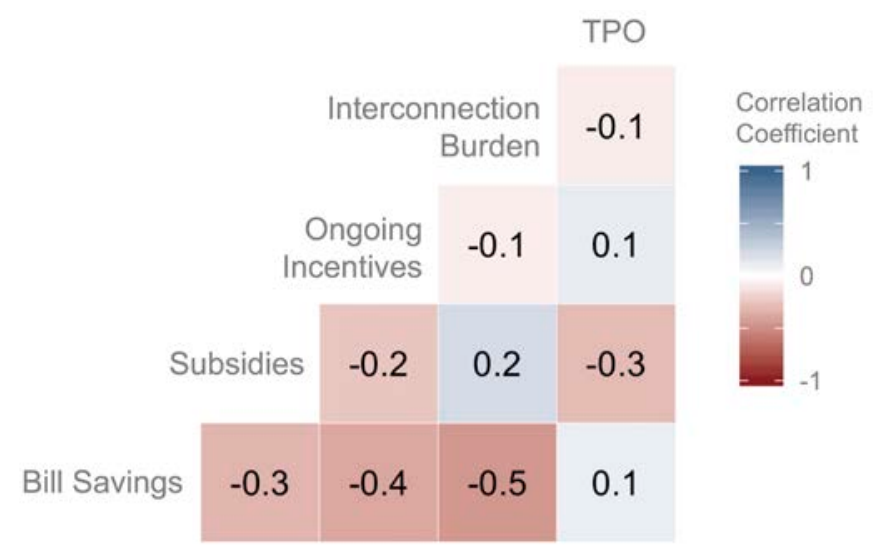

Figure 3. Policy variable correlations 


\subsection{Limitations}

A key assumption for a valid identification of policy effects is that policy affects industry but not vice-versa. In other words, it must be the case that PV policies are implemented independently from any consideration of local PV installation industries. This assumption may be faulty in certain contexts. For instance, policymakers may implement subsidies, at least in part, in order to attract more companies to install PV in local markets. This type of "reverse causality" could result in a spurious correlation between policies and industrial characteristics. The following section of descriptive statistics should be interpreted with this limitation in mind. In Section 3.6, a special econometric approach is developed that should reduce any estimation biases resulting from issues of reverse causality.

\subsection{Descriptive Statistics}

This section provides descriptive statistics for the data and variables. Focusing first on the dependent variable, Figure 4 illustrates the distribution of HHI measurements (left pane) and mean HHI measurements over time (right pane). A low HHI corresponds to an unconcentrated market, while a high HHI corresponds to a concentrated market - a market in which market shares are skewed toward high-volume installers. For context, the U.S. Department of Justice considers markets with an HHI below 0.15 to be unconcentrated, markets with HHI between 0.15 and 0.25 to be moderately concentrated, and markets with $\mathrm{HHI}$ above 0.25 to be concentrated. Half of the HHI measurements are below 0.19 , and $90 \%$ of $\mathrm{HHI}$ measurements are equal to or below 0.5 . The cluster of observations around HHI equal to 1 represents small markets with a single installer. Mean HHI ranged from 0.2 to 0.3 throughout the study period, with an increase from 2012 to 2014 followed by a decline from 2014 to 2016.

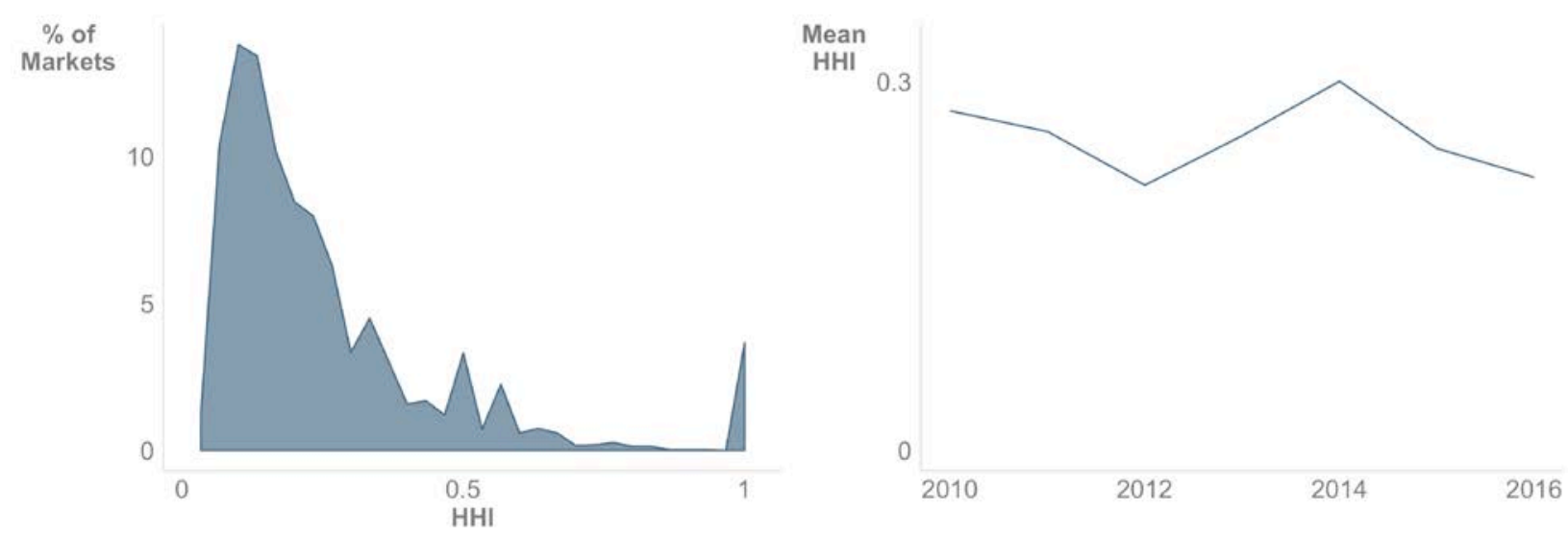

Figure 4. Distribution of HHI measurements (left) and HHI by year (right)

Moving to the independent variables, Figure 5 displays distributions for the values of the three financial incentives. Bill savings are generally higher in value than the other incentives are. Bill savings are higher than $\$ 2 / \mathrm{W}$ in about $64 \%$ of markets, compared to about $24 \%$ of markets for ongoing incentives and $12 \%$ of markets for subsidies. The cluster of markets centering around $\$ 4 / \mathrm{W}$ of bill savings primarily represents markets in California, where high volumetric rates and full retail rate net metering increase the value of bill savings for California customers. Ongoing incentives exhibit a bimodal distribution, with a cluster of zero or low ongoing incentive levels corresponding to markets without any ongoing incentives and a relatively low-value production- 
based incentive in Florida. The cluster of observations around \$2.5/W corresponds to SREC programs in Massachusetts and New Jersey.

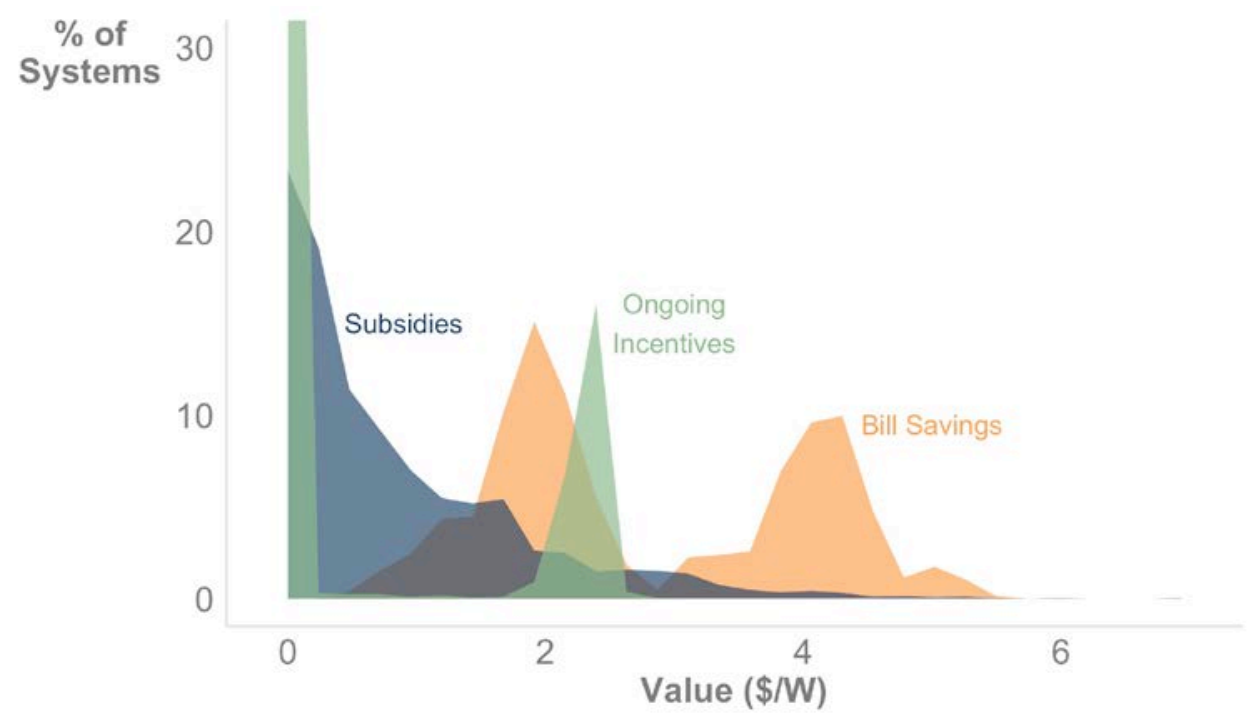

Figure 5. Distributions of incentive levels

$\mathrm{Y}$-axis is cropped for visual simplicity; the mode of observations for ongoing incentives exceeds $30 \%$.

Bill savings constitute the majority of the full value of PV adoption for the average PV customer (Figure 6). This result, like those in many results in PV studies, is strongly driven by the fact that California dominates the data. California customers paid relatively high volumetric rates and received relatively low rebates over the study period.

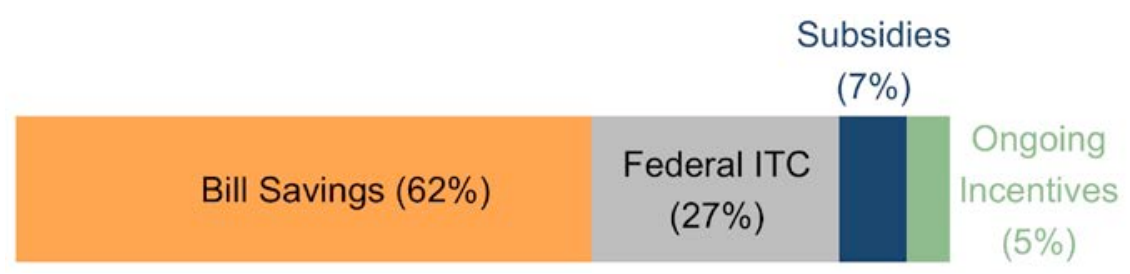

Figure 6. Breakdown of PV adoption values for average customer

Outside California, bill savings are still generally more valuable to customers than subsidies are (Figure 7). The values of subsidies and ongoing incentives nearly match or exceed the value of bill savings in several states, including Massachusetts, New Jersey, New York, and Oregon. Texas stands out as an outlier, where subsidies exceed the value of bill savings, primarily because Texas does not require utilities to offer net metering, and customers are compensated at an avoided-cost rate rather than the customer's retail rate. Note that Figure 7 is based on historical data. The values of the different incentives have changed and will continue to change as states and utilities update their net metering and incentive programs. 


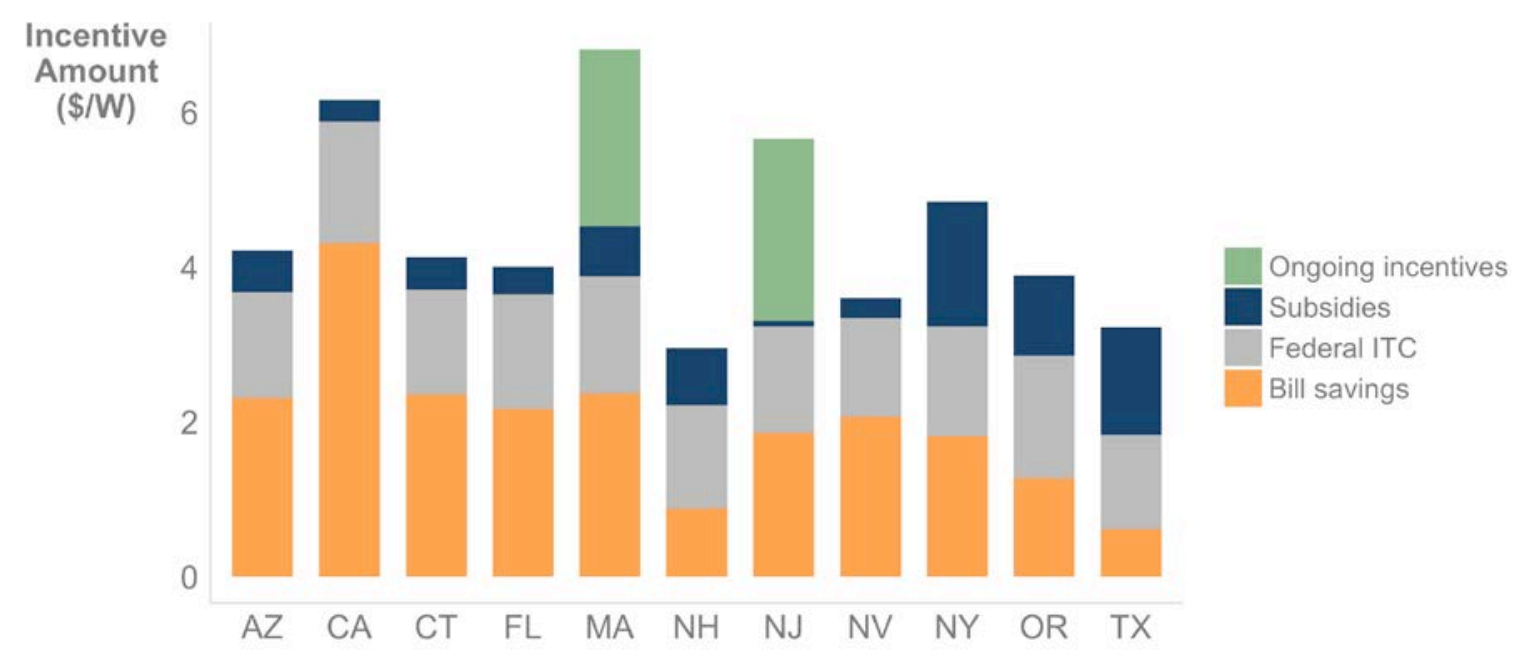

Figure 7. Breakdowns of PV adoption value by state

As noted in Section 2, state rebates have generally declined over time by program design. As a result, subsidy levels declined from 2010 to 2016 (Figure 8). In contrast, bill savings and ongoing incentive levels increased slightly over the study period, largely because customers bought increasingly larger PV systems over time, which increased system output and the sum of bill savings and SREC revenues.

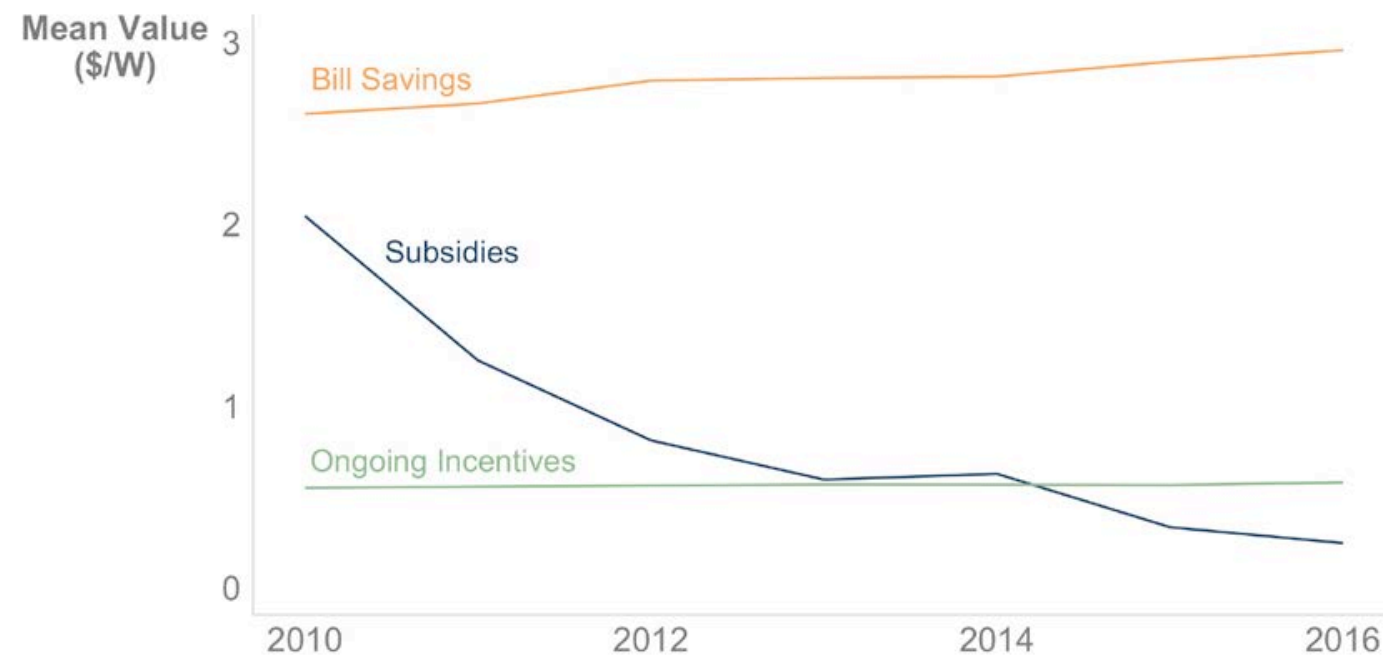

Figure 8. Mean incentive levels by year

About $42 \%$ of markets are in states with the lowest interconnection burden (score=1), about $49 \%$ are in states with a medium interconnection burden (score $=2)$, and about $9 \%$ are in states with a high interconnection burden (score $=3$ ). The relatively low frequency of markets in states with high interconnection burdens may reflect the difficulty of installing PV systems in markets with onerous interconnection requirements. 
Finally, Figure 9 illustrates the distribution of TPO penetrations (left pane) and mean TPO penetrations over time (right pane). TPO penetration shows a relatively even distribution, with about $52 \%$ of markets showing a TPO penetration below 0.5 . About $13 \%$ of markets have zero TPO systems. TPO penetration generally increased from 2010 to 2013 but has since stagnated and fallen slightly. Analysts have attributed the recent decline in TPO penetration to falling PV prices: as PV prices fall, the net benefits of system ownership begin to outweigh the net benefits of TPO (Perea et al. 2017; Litvak 2016).

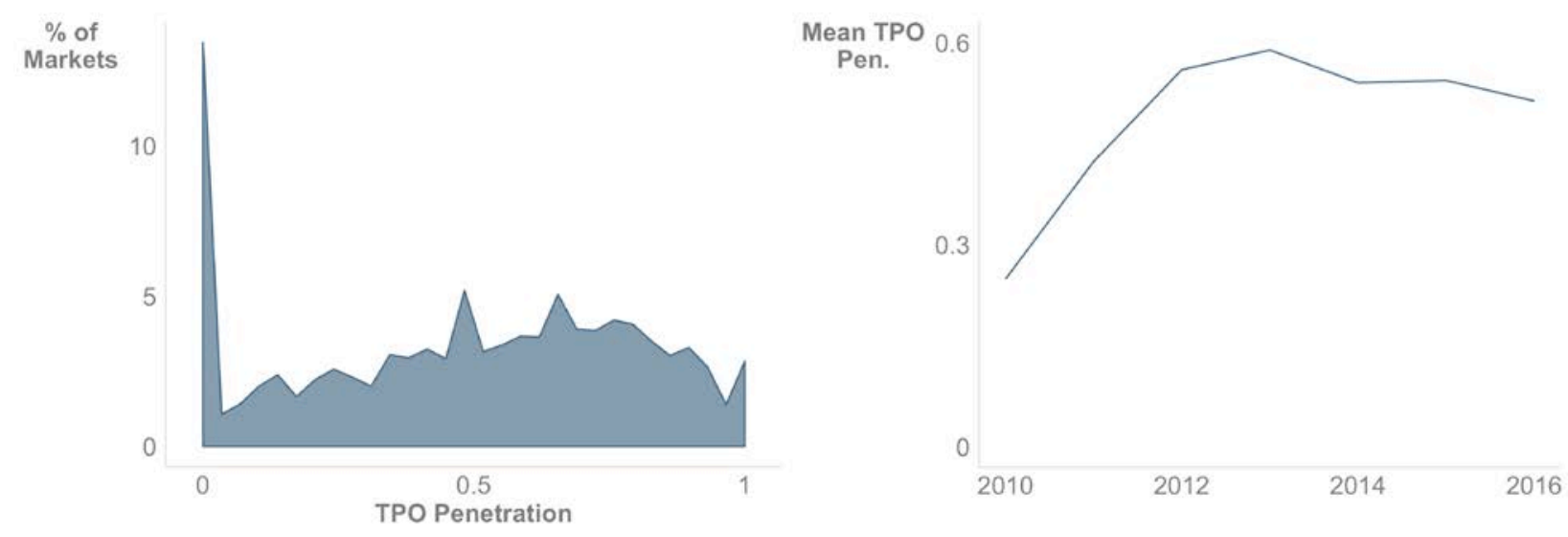

Figure 9. Distribution of TPO penetrations (left) and TPO penetration over time (right)

\subsection{Econometric Model}

An econometric model is used to correlate market structure variables with policy variables statistically. The econometric model can be represented as follows:

$$
M S=\mathbf{P O L} \alpha+\boldsymbol{X} \beta+\mathcal{M}+\mathcal{Y}+\varepsilon
$$

Where $M S$ is one of the three dependent market structure variables (number of installers, HHI, national-scale market share), POL denotes a vector of the five policy variables described in Section 2, $\boldsymbol{X}$ is a matrix of control variables, $\mathcal{M}$ represents market-level fixed effects, $\mathcal{Y}$ represents year-level fixed effects, and $\varepsilon$ is an error term. The coefficient $\alpha$ estimates the effects of policies on market structure. The coefficient $\beta$ measures the effects of the control variables.

The market-level fixed effects control for unobservable differences across markets that do not vary over time. For instance, populations in different markets may have unobservable differences in environmental awareness that could affect PV demand and market structure. The year-level fixed effects control for unobservable differences across time that do not vary across markets. For instance, customer familiarity with PV may have increased over time across all markets. Control variables are included that could affect market structure and may correlate with local policy contexts (see the appendix). Various demographic variables are included to control for how local populations could attract or deter PV installers and wield influence over policymakers to implement PV-friendly policies. Market prices are conspicuously absent from the control variables. High market prices may affect market concentration and may also induce policymakers to offer higher subsidies. However, market prices are not independent variables in Equation (2), given that market structure also affects prices (O'Shaughnessy 2018a), which poses various methodological issues for the regression. To avoid complicating the model with an 
endogenous control, market prices are excluded. The market and time fixed effects as well as the labor cost index should capture the effects of this omitted variable.

The model represented in Equation (2) requires the assumption that the policy variables are independent, meaning the values of the variables do not depend on an omitted variable or the dependent market structure variable. When a regression variable is not truly independent, it is said to be endogenous. Endogeneity may be an issue in Equation (2) if the causal direction can reverse between policy and market structure. For instance, policymakers may implement rebates to attract more installers into markets with small installation industries. In this case, policy is partially a reaction to - rather than a cause of - market structure. Endogenous models can yield biased regression coefficients.

Geographic discontinuities such as utility borders provide one way to address potentially endogenous policies. The rationale is that the installation industry on either side of a utility border should be similar, assuming no legal or physical barriers prevent installers from freely conducting business on either side. Consistent with previous studies (Bollinger and Gillingham 2012; Hughes and Podolefsky 2015), the border between Pacific Gas \& Electric (PG\&E) and Southern California Edison (SCE) is used as a geographic discontinuity in this study. The PG\&E/SCE border provides an ideal discontinuity because the border was determined in the early 1900s, long before PV markets could influence the position of the border (Hughes and Podolefsky 2015). Further, contractors are licensed at the state level in California, so installers can freely conduct business on either side of the border. Finally, because rate structures and rebate levels are determined at the utility level, market structure in the fringe region at the PG\&E/SCE border should have minimal impact on the policies at the utility level (Hughes and Podolefsky 2015).

A balanced panel data set was created using 38 ZIP codes in a 20-mile corridor around the border (Figure 10, right pane), which is consistent with Hughes and Podolefsky (2015). Markets are defined at the ZIP code level. Subsidy levels varied over time on either side of the border based on a declining rebate schedule set for each major utility in California, though the average received rebate temporarily increased in PG\&E in 2014 (Figure 10, left pane). Rate structures also varied on either side of the border based on variations in volumetric rates. Both utilities offered full retail rate net metering. The state-level ITC is excluded from the calculation of the subsidy level. Ongoing incentives were unavailable in California during the study period and are excluded from the model. The state-level interconnection burden score is excluded from the model. The results of the geographic discontinuity model are presented in Section 4.1.2. 


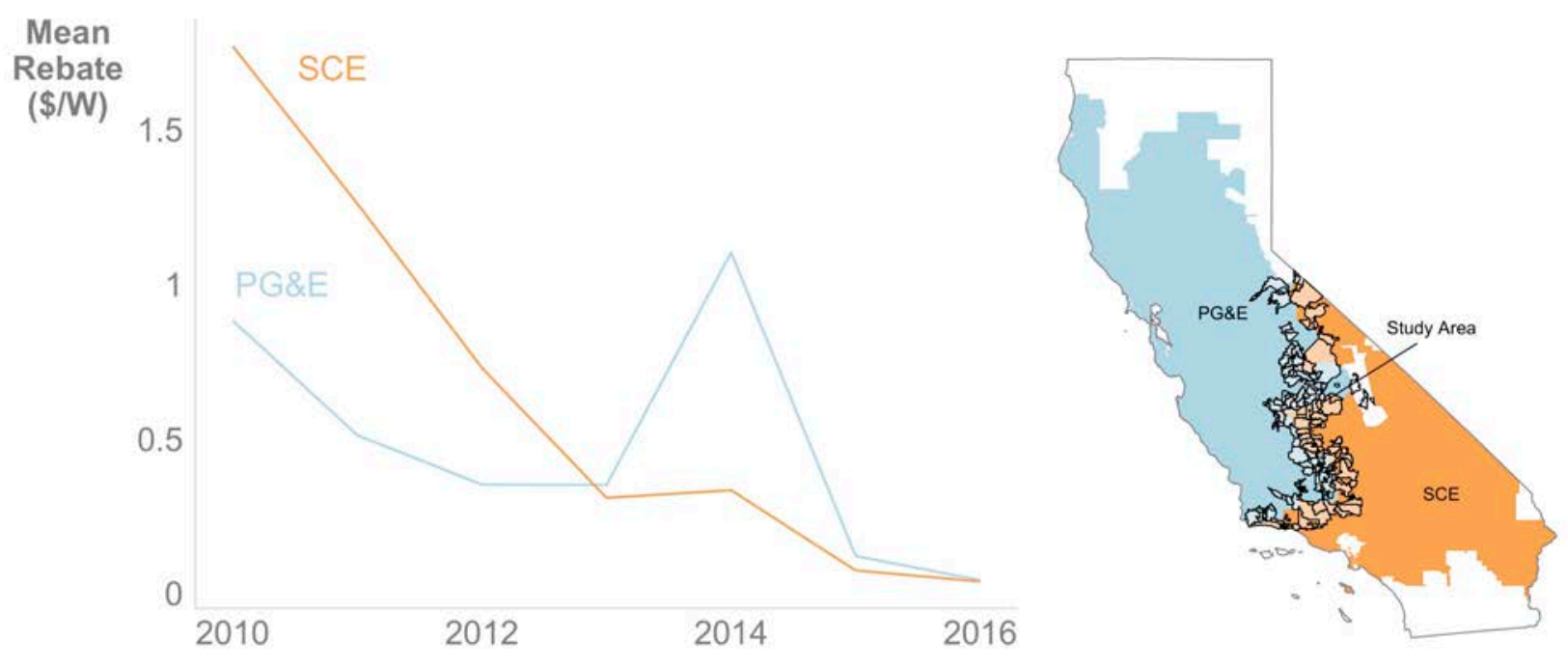

Figure 10. Study area in 20-mile corridor around PG\&E/SCE border (right) and subsidy levels over time on either side of the border (left) 


\section{Results}

Table 2 provides the results of the model in Equation (2) for each of the three dependent market structure variables. The coefficients may be interpreted as a unit change in the dependent variable resulting from a unit change in the independent variable. For instance, the first row of results can be read as a $\$ 1 / \mathrm{W}$ increase in bill savings associated with an increase of 21.28 installers, a 0.10 point reduction in HHI, and a 7.5 percentage point reduction in the market share of national-scale installers. The coefficients on each interconnection burden score are interpreted as the effects of increasing interconnection burden by moving from a market with the lowest interconnection burden score of 1 to each respective score. The coefficient on the TPO variable is interpreted as the effect of moving from a market with no TPO to a market where all systems are TPO.

Table 2. Econometric Model Results

Heteroskedasticity-robust t statistics in parentheses

\begin{tabular}{|c|c|c|c|}
\hline & $\begin{array}{c}(1) \\
Y=\# \text { installers }\end{array}$ & $\begin{array}{c}(2) \\
Y=H H I\end{array}$ & $\begin{array}{c}(3) \\
Y=\% \text { national }\end{array}$ \\
\hline Bill savings $(\$ / W)$ & $\begin{array}{l}21.28^{\mathrm{a}} \\
(7.99)\end{array}$ & $\begin{array}{l}-0.10^{a} \\
(3.19)\end{array}$ & $\begin{array}{r}7.46^{\mathrm{a}} \\
(2.85) \\
\end{array}$ \\
\hline Subsidies $(\$ / W)$ & $\begin{array}{l}-2.33^{a} \\
(5.38) \\
\end{array}$ & $\begin{array}{r}0.05^{a} \\
(6.38) \\
\end{array}$ & $\begin{array}{r}-9.81^{a} \\
(13.90) \\
\end{array}$ \\
\hline Ongoing incentives $(\$ / W)$ & $\begin{array}{l}-7.55^{a} \\
(3.65) \\
\end{array}$ & $\begin{array}{l}-0.03 \\
(0.65) \\
\end{array}$ & $\begin{array}{r}-12.11^{a} \\
(2.79) \\
\end{array}$ \\
\hline Interconnection burden (2) & $\begin{array}{c}1.26 \\
(1.83)\end{array}$ & $\begin{array}{l}-0.05^{a} \\
(3.85)\end{array}$ & $\begin{array}{c}2.23 \\
(1.69)\end{array}$ \\
\hline Interconnection burden (3) & $\begin{array}{r}3.62^{\mathrm{a}} \\
(2.86) \\
\end{array}$ & $\begin{array}{c}0.08 \\
(1.67) \\
\end{array}$ & $\begin{array}{r}9.90^{a} \\
(3.47) \\
\end{array}$ \\
\hline TPO & $\begin{array}{l}-9.16^{\mathrm{a}} \\
(7.91)\end{array}$ & $\begin{array}{r}0.07^{a} \\
(3.80)\end{array}$ & $\begin{array}{r}28.86^{a} \\
(14.76) \\
\end{array}$ \\
\hline Sales tax $(\$ / W)$ & $\begin{array}{r}-42.70^{a} \\
(7.22)\end{array}$ & $\begin{array}{l}-0.26^{a} \\
(2.92) \\
\end{array}$ & $\begin{array}{r}-22.67^{a} \\
(3.02) \\
\end{array}$ \\
\hline Market size & $\begin{array}{c}0.009 \\
(0.50)\end{array}$ & $\begin{array}{c}0.000^{a} \\
(2.72)\end{array}$ & $\begin{array}{l}0.009^{b} \\
(2.42)\end{array}$ \\
\hline Entry pool & $\begin{array}{c}1.27 \\
(1.27)\end{array}$ & $\begin{array}{l}-0.001 \\
(1.03)\end{array}$ & $\begin{array}{l}-0.21 \\
(0.89)\end{array}$ \\
\hline Labor cost index & $\begin{array}{l}-0.01 \\
(1.10)\end{array}$ & $\begin{array}{l}-0.000 \\
(1.37) \\
\end{array}$ & $\begin{array}{c}0.04 \\
(1.40) \\
\end{array}$ \\
\hline Household density & $\begin{array}{c}0.39 \\
(0.90)\end{array}$ & $\begin{array}{l}-0.02^{a} \\
(2.98)\end{array}$ & $\begin{array}{c}0.87 \\
(0.52)\end{array}$ \\
\hline$\%$ higher than bachelor's degree & $\begin{array}{l}-0.13 \\
(1.63) \\
\end{array}$ & $\begin{array}{l}-0.001 \\
(0.85) \\
\end{array}$ & $\begin{array}{l}-0.30^{\mathrm{b}} \\
(2.12) \\
\end{array}$ \\
\hline$\%$ income $>\$ 100 \mathrm{k}$ & $\begin{array}{l}-0.21^{\mathrm{b}} \\
(2.07) \\
\end{array}$ & $\begin{array}{l}-0.001 \\
(0.65) \\
\end{array}$ & $\begin{array}{l}-0.41^{\mathrm{b}} \\
(2.31) \\
\end{array}$ \\
\hline constant & $\begin{array}{l}-6.76 \\
(0.65)\end{array}$ & $\begin{array}{r}1.00^{\mathrm{a}} \\
(3.50)\end{array}$ & $\begin{array}{l}-1.34 \\
(0.06)\end{array}$ \\
\hline$R^{2}$ & 0.55 & 0.08 & 0.41 \\
\hline$N$ & 3,738 & 3,738 & 3,738 \\
\hline
\end{tabular}

a Statistically significant at $p<0.01 ;{ }^{b} p<0.05$ 
The effects of bill savings agree with theoretical expectations based on the discussion in Section 2. Markets with higher bill savings are associated with industries with more installers: a \$1/W increase in bill savings is associated with an increase of about 21 installers, which translates to an increase of about $80 \% .{ }^{4}$ This result supports the hypothesis that higher bill savings increase customer demand and installation profitability, inducing installers to enter and remain in these markets. Markets with higher bill savings also tend to be less concentrated, implying that market shares are more evenly distributed among installers. The effects of bill savings on the market share of national-scale installers are not statistically significant.

Higher subsidies are associated with markets with fewer installers and with more concentrated markets. These results run counter to expectations based on the notion that subsidies increase installation profitability by increasing demand and should, all else being equal, increase installation market entry. Higher subsidies are also associated with markets where national-scale installers hold a lower market share: the results indicate a $\$ 1 / \mathrm{W}$ increase in subsidies reduces national-scale market share by 9.8 percentage points.

Higher ongoing incentives are associated with markets with fewer installers and markets where national-scale installers hold less market share. Similar to the result for subsidies, the inverse relationship between ongoing incentives and the number of installers counters theoretical expectations.

The coefficients on the interconnection burden variable are mostly insignificant. The weak effects may represent a truly weak effect, but they may also reflect lack of variation in the variable. All the coefficients on the TPO variable agree with theoretical expectations. Markets with higher TPO penetrations tend to be more concentrated. The effect of TPO on the market share of national-scale installers is positive and highly significant, largely because the nationalscale installers primarily offer TPO systems. See Section 2.2 for an explanation of this result.

\subsection{Robustness Checks}

This section tests the robustness of the results in Table 2, first by applying the model with county as an alternative market definition and then by applying the geographic discontinuity approach described in Section 3.5. A result is robust if a) the original coefficient is statistically significant, b) the sign of the original coefficient is preserved (i.e., positive or negative), and c) the coefficient remains statistically significant. A result is semi-robust if conditions a and b are met but $\mathrm{c}$ is not. For simplicity, the robustness results are highlighted according to the following scheme:

\begin{tabular}{l|l|l} 
Robust & Semi-Robust & Not Robust \\
\hline
\end{tabular}

\subsubsection{Alternative Market Definition}

To test whether the results are sensitive to market definition, Table 3 presents the coefficients for the model with the three dependent variables with county boundaries as an alternative market definition. All the statistically significant results from the base model are at least semi-robust.

\footnotetext{
${ }^{4}$ Based on the regression coefficient with a logged number of installers
} 
Table 3. Policy Variable Coefficients, Markets = Counties

Original results in parentheses

\begin{tabular}{|c|c|c|c|}
\hline & $\begin{array}{c}(1) \\
Y=\# \text { installers }\end{array}$ & $\begin{array}{c}(2) \\
Y=H H I\end{array}$ & $\begin{array}{c}(3) \\
Y=\% \text { national }\end{array}$ \\
\hline Bill savings & $21.9^{a}{ }_{(21.3)}$ & $-0.07(-0.1)$ & $13.1^{\mathrm{b}}(7.5)$ \\
\hline Subsidies & $-2.1^{a}{ }_{(-2.3)}$ & $0.05^{\mathrm{a}}(0.05)$ & $-10.9^{a}(-9.8)$ \\
\hline Ongoing incentives & $-6.8(-7.6)$ & $-0.24^{\mathrm{b}}(-0.03)$ & $-1.7(-12.1)$ \\
\hline Interconnection (2) & $2.6(1.3)$ & $-0.07^{a}(-0.05)$ & $1.9_{(2.2)}$ \\
\hline Interconnection (3) & $1.9_{(3.6)}$ & $-0.007(0.08)$ & $8.0(9.9)$ \\
\hline TPO & $-8.1^{\mathrm{a}}(-9.2)$ & $0.07^{\mathrm{b}}(0.07)$ & $30.1^{a}(28.9)$ \\
\hline
\end{tabular}

a Statistically significant at $p<0.01 ; b p<0.05$

\subsubsection{Geographic Discontinuity}

As discussed in Section 3.5, some of the policy variables may be at least partially endogenous, meaning the variables are not truly independent in Equation (2), and the regression model results may be biased. Endogeneity may be of particular concern for the subsidy variable. Indeed, the spurious temporal correlation of declining rebates and increasing number of installers may partially explain the surprising coefficients on the subsidies in Table 2.

Table 4 provides the results of the geographic discontinuity model described in Section 3.5. The signs on most of the coefficients are consistent with the base models. All the results are at least semi-robust. Subsidy levels still inversely correlate with the market share of national-scale installers, though the effect is no longer statistically significant.

Table 4. Regression Results Limited to Corridor at PG\&E/SCE Border Original results in parentheses

\begin{tabular}{lccc}
\hline & $\begin{array}{c}(\mathbf{1}) \\
\text { Y=\# installers }\end{array}$ & $\begin{array}{c}\text { (2) } \\
\text { Y=HHI }\end{array}$ & $\begin{array}{c}\text { (3) } \\
\text { \%national }\end{array}$ \\
\hline Bill savings $(\$ / W)$ & $3.9^{\mathrm{b}}(21.3)$ & $-0.1_{(-0.1)}$ & $17.9_{(7.5)}$ \\
Subsidies $(\$ / \mathrm{W})$ & $-5.9^{\mathrm{a}}(-2.3)$ & $0.2^{\mathrm{a}}(0.05)$ & $-3.9_{(-9.8)}$ \\
TPO & $-4.8^{\mathrm{b}}(-9.2)$ & $0.1_{(0.07)}$ & $31.6^{\mathrm{a}}(28.9)$ \\
\hline$N$ & 266 & 266 & 266 \\
\hline
\end{tabular}

a Statistically significant at $p<0.01 ;{ }^{b} p<0.05$

One potential limitation of the geographic discontinuity approach is limited external validity: it is unclear whether the results in Table 4 can be extrapolated to apply to markets outside California. Further, the results of the base model may be dominated by trends in California, given that California accounts for about $63 \%$ of systems in the data set. As a final robustness check to assess the validity of the results outside of California, Table 5 presents regression results while excluding systems installed in California. The effects of the financial incentives are again largely robust, suggesting the factors that drive the observed relationships between incentives and market structure are not exclusive to markets in California. Interestingly, higher levels of TPO penetration are associated with markets with more installers outside California, contrary to the effects for that variable in previous models. This result suggests TPO penetration may shift market shares toward high-volume installers, but not necessarily by reducing the number of installers overall. 
Table 5. Regression Results Excluding California ( $N=301)$

Original results in parentheses

\begin{tabular}{|c|c|c|c|}
\hline & $\begin{array}{c}(1) \\
Y=\# \text { installers }\end{array}$ & $\begin{array}{c}(2) \\
Y=H H I\end{array}$ & $\begin{array}{c}(3) \\
Y=\% \text { national }\end{array}$ \\
\hline Bill savings & $2.9^{b}(21.3)$ & $-0.2^{b}(-0.1)$ & $7.0_{(7.5)}$ \\
\hline Subsidies & $-1.4^{a}(-2.3)$ & $0.03^{\mathrm{b}}(0.05)$ & $-10.5^{\mathrm{a}}(-9.8)$ \\
\hline Ongoing incentives & $2.4(-7.6)$ & $-0.01(-0.03)$ & $-6.9(-12.1)$ \\
\hline Interconnection (2) & $1.1^{\mathrm{b}}(1.3)$ & $-0.10^{\mathrm{b}}(-0.05)$ & $10.9_{(2.2)}$ \\
\hline Interconnection (3) & $-0.4(3.6)$ & $0.05_{(0.08)}$ & $14.7^{\mathrm{a}}(9.9)$ \\
\hline TPO & $0.8(-9.1)$ & $0.07^{a}(0.07)$ & $33.6^{a}(28.9)$ \\
\hline
\end{tabular}

a Statistically significant at $p<0.01 ;{ }^{b} p<0.05$

\subsection{Results Summary}

Figure 11 summarizes the results by the signs and robustness levels of the policy effects on the three market structure variables.

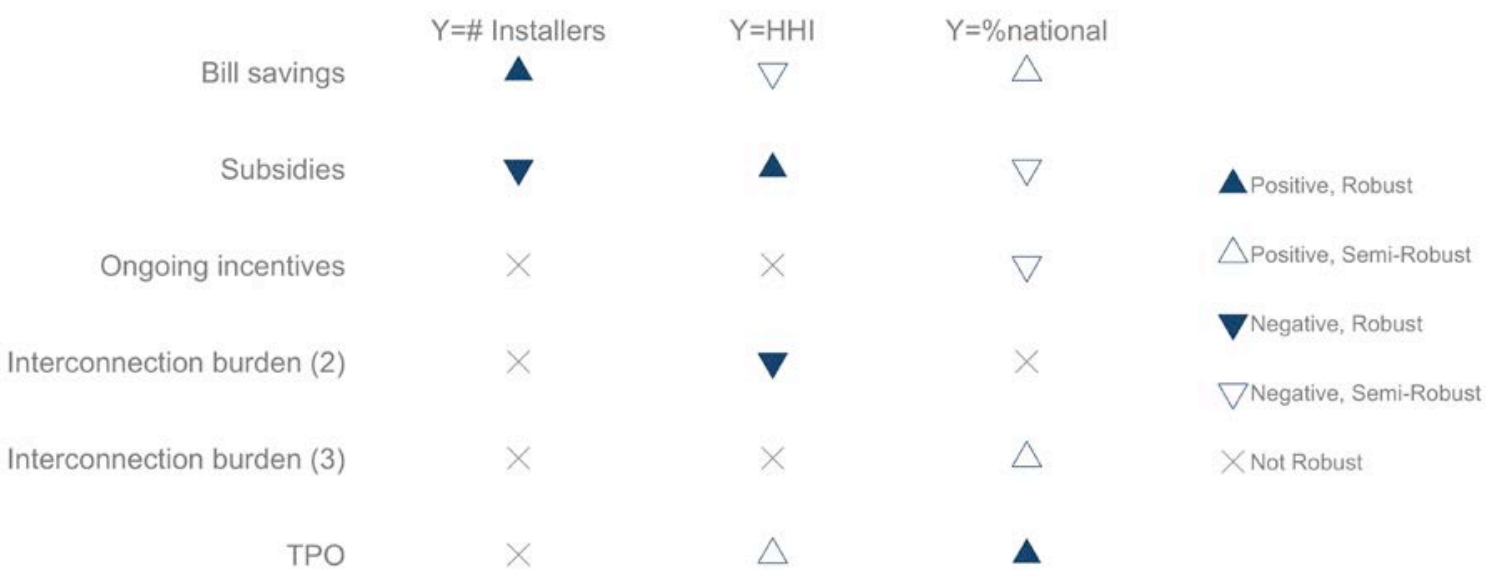

Figure 11. Summary of effects of policies on PV market structure variables

The figure shows that:

- Bill savings have a robust positive impact on the number of installers and a semi-robust negative impact on $\mathrm{HHI}$.

- Subsidies have robust impacts on the number of installers (negative) and HHI (positive) and a negative semi-robust impacts on the market share of national-scale installers.

- Ongoing incentives have a semi-robust negative impacts on national-scale installer market share.

- Higher interconnection burden has a robust negative impact on HHI and a semi-robust positive impact on national-scale installer market share.

- TPO penetration has a semi-robust positive impact on HHI and a robust positive impact on the market share of national-scale installers. 
Table 6 summarizes the results relative to the hypotheses developed in Section 2.2. The results support hypotheses that higher bill savings result in markets with more installers and that TPO policies result in markets with higher-volume installers, but they counter the hypothesis that subsidies result in markets with more installers. The effect of ongoing incentives on the number of installers was not robust, providing an inconclusive result to the hypothesis. However ongoing incentives had negative robust impacts on the market share of national-scale installers. The effects of interconnection burden were generally insignificant and not robust.

Table 6. Results Compared with Hypotheses

\begin{tabular}{lll}
\hline \multicolumn{1}{c}{ Policy } & \multicolumn{1}{c}{ Hypothesis } & Result \\
\hline Bill savings & $\begin{array}{l}\text { Higher bill savings induce market entry, result in markets with } \\
\text { more installers }\end{array}$ & Supported \\
Subsidies & $\begin{array}{l}\text { Higher subsidies induce market entry, result in markets with more } \\
\text { installers }\end{array}$ & Rejected \\
$\begin{array}{l}\text { Ongoing } \\
\text { incentives }\end{array}$ & $\begin{array}{l}\text { Higher ongoing incentives induce market entry, result in markets } \\
\text { with more installers }\end{array}$ & Inconclusive \\
$\begin{array}{l}\text { Interconnection } \\
\text { burden }\end{array}$ & $\begin{array}{l}\text { Higher interconnection burden reduces market entry, results in } \\
\text { markets with fewer installers }\end{array}$ & Inconclusive \\
TPO & $\begin{array}{l}\text { More TPO penetration increases returns to scale, results in shift of } \\
\text { market shares toward higher-volume installers (higher HHI) }\end{array}$ & Supported \\
\hline
\end{tabular}




\section{Discussion and Conclusion}

As predicted, more residential PV installers compete in markets where customers can expect higher bill savings. Surprisingly, however, fewer installers compete in markets where customers are eligible for higher upfront subsidies. In other words, a policy to increase bill savings by $\$ 1 / \mathrm{W}$ would have the opposite effect on the industry of a policy to implement a subsidy with the same value. These findings indicate the impacts of financial incentives on local installation industries depend on how those incentives accrue to customers, not only on the value of the incentives. In this section, several hypotheses are explored that provide plausible explanations for these results. This discussion is meant primarily to motivate future research; the hypotheses cannot be proved or disproved using the results from the current study.

One potential explanation is that bill savings and subsidies affect installer strategies in different ways. In markets with high bill savings, installers may offer higher prices to increase profit margins, in a practice known as "value-based" pricing. If so, some otherwise-inefficient high-cost installers may be able to compete in markets with high bill savings, thus increasing the number of competing installers overall. In markets with subsidies, installers may focus on market shares rather than margins, passing the subsidies through to customers and keeping prices low. Such a strategy could make sense given the short-term nature of subsidy programs. By temporarily cutting profit margins, installers can establish a market foothold while customers are eligible for subsidies and then earn long-term profits through a stronger market position after the subsidy program has expired. If so, intense price competition in markets with subsidies would limit the market to efficient low-cost installers and reduce the number of competing installers overall.

Two pieces of evidence support the theory that bill savings and subsidies affect installer strategies in this way. First, multiple studies find that installers indeed "pass through" subsidies to customers (Pless and van Benthem 2017; Dong, Wiser, and Rai 2018). The fact that installers do not keep the subsidies for themselves suggests installers prioritize market share over profit margins. In contrast, Bielen et al. (forthcoming) show that installers of TPO systems largely keep the value of bill savings by offering higher prices to customers with higher bill savings, which is consistent with a value-based pricing strategy. Second, a 2017 installer survey found that $62 \%$ of installers strategically prioritize increasing market share rather than increasing profits (EnergySage 2018). Comparing the survey results with TTS incentive data shows that installers are more likely to implement market share strategies in states with higher incentive levels (including ongoing incentives) (Figure 12). For example, about 69\% of installers reported implementing market share strategies in New York, where rebates had not declined as much as other major markets by 2016 (see Figure 1). In contrast, about $42 \%$ of installers reported implementing market share strategies in California, where rebates had largely been exhausted by 2016. Market share strategies are particularly common in Massachusetts and New Jerseys, two states with relatively attractive ongoing incentives (i.e., SRECs). Similar to subsidies, ongoing incentives were likewise associated with fewer installers in the base model, but this result was not robust in the county-market model. These correlations are consistent with the notion that bill savings cause installers to focus on margins, whereas subsidies cause installers to focus on market share. The effects of bill savings and subsidies on installer strategies are an area for further research. 


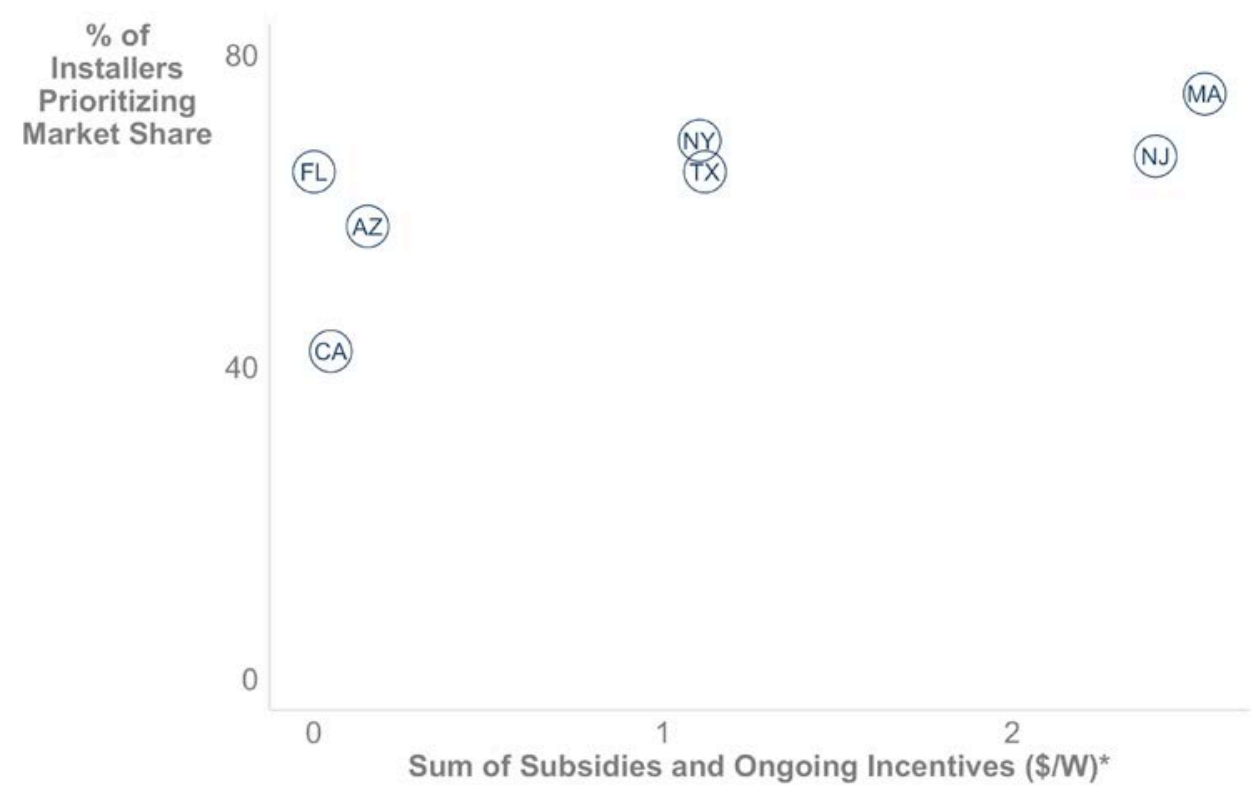

Figure 12. Correlation between percentage of installers implementing a market share strategy and the sum of state-level subsidies and ongoing incentives

\begin{abstract}
Installer strategy data are based on survey responses from EnergySage (2018) and are limited to states with responses from at least 10 installers. *The sum of subsidies and ongoing incentives is based on 2016 mean values, which are likely slightly higher than current levels, owing to declining incentive levels.
\end{abstract}

Another interesting result is that higher subsidies and ongoing incentives are associated with markets where national-scale installers hold less market share. There are two plausible explanations for this outcome. First, subsidy levels inversely correlate with TPO penetration (see Figure 3), possibly because subsidies reduce the upfront cost of system ownership and make customer ownership more attractive than TPO. Thus subsidies may support local installers by reducing the relative value of the TPO products on offer from national-scale installers. However, this explanation could not explain why ongoing incentives are similarly associated with lower national-scale installer market shares. Second, local installers may have competitive advantages in markets with subsidies and ongoing incentives, perhaps because these installers better understand the nuances of the programs, or because subsidy/incentive programs channel customers to local installers. For instance, rebate program websites may list qualified local installers, or local Solarize ${ }^{5}$ programs may work with local installers to help customers take advantage of rebates. The provision of subsidies and ongoing incentives may therefore support the development of local PV installation industries. This hypothesis is an area for further research.

The results of this analysis may have implications for PV markets in service areas undergoing rate reforms. At least 17 states have proposed or implemented reforms to reduce or eliminate net metering (Proudlove et al. 2018a). Several utilities have proposed or implemented rate structures that generally reduce bill savings from PV, including higher fixed charges, time-of-use (TOU)

\footnotetext{
${ }^{5}$ In a Solarize program, a community group contracts with an installer or installers to install systems on multiple homes.
} 
rates, ${ }^{6}$ and demand charges (\$ per kW of peak demand) (Proudlove et al. 2018a). Both of these trends reduce the value of PV bill savings. These state and utility policy reforms could reduce PV demand and cause stiffer price competition between installers for the remaining customers. As a result, these rate reforms could result in more-concentrated markets with fewer installers as some high-cost installers are priced out of these markets.

The implications of rate reform-induced reductions in numbers of local installers depend on local policy objectives and must be assessed against other policy priorities. On one hand, a reduction in the number of installers may reduce local economic activity and PV customer choice. On the other hand, rate reforms may induce installers to innovate and develop new products that cater to customers with lower bill savings. For instance, customers with lower net-metering rates and TOU rates face incentives to invest in devices such as batteries and home energy management systems. These devices allow customers to store PV output and shift loads in ways that increase bill savings from PV systems, and they could have grid-level benefits. Rate reforms may nudge local installation industries to integrate these devices.

The finding that subsidies and ongoing incentives appear to support regional and local installers more than national-scale installers may have implications for emerging PV markets. Emerging markets may view subsidy and other incentive programs as a way to kickstart local PV installation industries, perhaps designing them specifically for this purpose by, for example, listing qualified local installers on a subsidy program website. Short-term subsidy programs may allow local companies to accumulate installation expertise and establish themselves before national-scale installers move in to the market. The desirability of this outcome depends on local policy objectives. Supporting regional and local installers may support local businesses and increase local economic benefits. At the same time, national-scale installers are often better positioned than local installers to offer customer financing options such as TPO and solar loans. These PV financing products may be particularly important to cash-constrained customers. An optimal policy mix may simultaneously support local installers (e.g., rebate programs that channel customers to local installers) while reducing barriers to entry for national-scale installers (e.g., opening markets to TPO).

At a more basic level, the results of this study may inform future PV policy analysis. For example, suppose a jurisdiction is considering implementing a $\$ 1 / \mathrm{W} P V$ rebate. A direct policy analysis would estimate the effects of a $\$ 1 / \mathrm{W}$ reduction in post-incentive prices on local PV adoption. The results of this study indicate the rebate could also yield a more concentrated market with fewer installers, possibly because of the effects of subsidies on installer strategies. The results also suggest the rebate could reduce the market shares of national-scale installers in favor of regional and local installers. A comprehensive PV policy analysis would need to account for these various indirect effects on PV prices, adoption rates, and local economic impacts. Future analyses and modeling exercises could use the results of this study to correct the errors associated with changes in the PV installation industry.

\footnotetext{
${ }^{6}$ In a TOU rate, bill savings are determined by the volumetric rate applied during the daytime PV output period. PV output hours are generally off-peak in most TOU structures, such that the relevant volumetric rate is lower during the PV output period.
} 
To conclude, this study uses a data-driven approach to study the effects of state and local policies on local PV installation industries. The analysis shows that more installers tend to compete in markets where customers earn greater bill savings from PV adoption, but that fewer installers compete in markets with higher subsidies. These results suggest that the effects of policies on PV installation industries depend on how those policies affect the value of PV adoption, not only on how much. The potentially heterogeneous effects of policies on installer strategies are one area for further research. Furthermore, the results indicate subsidies and ongoing incentives tend to support regional and local installers more than national-scale installers. Finally, the results confirm expectations that higher levels of TPO penetration are associated with markets where high-volume and national-scale installers hold more market share. Policymakers may want to explore policy mixes that balance multiple policy objectives, such as supporting local installers while also attracting high-volume installers that can offer innovative customer financing options. 


\section{References}

Ardani, Kristen, Carolyn Davidson, Robert Margolis, and Erin Nobler. 2015. A State-Level Comparison of Processes and Timelines for Distributed Photovoltaic Interconnection in the United States. Golden, CO: National Renewable Energy Laboratory.

Barbose, Galen, and Naim Darghouth. 2017. Tracking the Sun 10: The Installed Price of Residential and Non-Residential Photovoltaic Systems in the United States. Berkeley, CA: Lawrence Berkeley National Laboratory.

Beck, Frederick, and Eric Martinot. 1994. Renewable Energy Policies and Barriers." Encyclopedia of Energy (Elsevier).

Bielen, D., E. O'Shaughnessy, B. Sigrin, and R. Margolis. Forthcoming. Value Accrual to Customers, Installers, and Financiers in Third-Party Owned Solar PV Markets. Golden, CO: National Renewable Energy Laboratory.

Bollinger, B., and K. Gillingham. 2012. "Peer Effects in the Diffusion of Solar Photovoltaic Panels," Marketing Science 31: 900-12.

Borenstein, S. 2017. "Private Net Benefits of Residential Solar PV: The Role of Electricity Tariffs, Tax Incentives, and Rebates," Journal of the Association of Environmental and Resource Economists 4: S85-S122.

Burkhardt, J., R. Wiser, N. Darghouth, C. G. Dong, and J. Huneycutt. 2015. Exploring the Impact of Permitting and Local Regulatory Processes on Residential Solar Prices in the United States," Energy Policy 78: 102-12.

Burrows, P. 1979. "Pigovian Taxes, Polluter Subsidies, Regulation, and the Size of a Polluting industry," Canadian Journal of Economics-Revue Canadienne D Economique 12: 494-501.

Chung, Donald, Kelsey Horowitz, and Parthiv Kurup. 2016. Emerging Opportunities and Challenges in U.S. Solar Manufacturing. Golden, CO: National Renewable Energy Laboratory.

Conrad, K., and J. M. Wang. 1993. "The Effect of Emission Taxes and Abatement Subsidies on Market Structure," International Journal of Industrial Organization 11: 499-518.

Crago, C. L., and I. Chernyakhovskiy. 2017. "Are Policy Incentives for Solar Power Effective? Evidence from Residential Installations in the Northeast," Journal of Environmental Economics and Management 81: 132-51.

Currier, K. M. 2015. "Some Implications of Investment Cost Reduction Policies in Energy Markets Employing Green Certificate Systems," Environmental \& Resource Economics 60: 317 23.

Darghouth, N. R., R. H. Wiser, and G. Barbose. 2016. "Customer Economics of Residential Photovoltaic Systems: Sensitivities to Changes in Wholesale Market Design and Rate Structures," Renewable \& Sustainable Energy Reviews 54: 1459-69. 
Darghouth, Naim, Galen Barbose, and Ryan Wiser. 2013. Electricity Bill Savings from Residential Photovoltaic Systems: Sensitivities to Changes in Future Electricity Market Conditions. Berkeley, CA: Lawrence Berkeley National Laboratory.

Dong, Changgui, and Ryan Wiser. 2013. "The Impact of City-Level Permitting Processes on Residential Photovoltaic Installation Prices and Development Times: An Empirical Analysis of Solar Systems in California Cities," Energy Policy 63: 531-42.

Dong, Changgui, Ryan Wiser, and Varun Rai. 2018. "Incentive Pass-Through for Residential Solar Systems in California," Energy Economics 72: 154-65.

Drury, E., M. Miller, C. M. Macal, D. J. Graziano, D. Heimiller, J. Ozik, and T. D. Perry. 2012. "The Transformation of Southern California's Residential Photovoltaics Market through ThirdParty Ownership," Energy Policy 42: 681-90.

Dunne, T., S. D. Klimek, M. J. Roberts, and D. Y. Xu. 2013. "Entry, Exit, and the Determinants of Market Structure," Rand Journal of Economics 44: 462-87.

EnergySage. 2018. Solar Installer Survey 2017 Results. EnergySage.

Freeing The Grid. 2018. Best Practices in State Net Metering Policies and Interconnection Procedures. Freeing The Grid.

Gillingham, K., H. Deng, R. Wiser, N. R. Darghouth, G. Nemet, G. Barbose, V. Rai, and C. G. Dong. 2016. "Deconstructing Solar Photovoltaic Pricing: The Role of Market Structure, Technology, and Policy," Energy Journal 37: 231-50.

Hughes, Jonathan E., and Molly Podolefsky. 2015. "Getting Green with Solar Subsidies: Evidence from the California Solar Initiative," Journal of the Association of Environmental and Resource Economists 2: 235-75.

Katsoulacos, Y., and A. Xepapadeas. 1995. "Environmental Policy Under Oligopoly with Endogenous Market Structure," Scandinavian Journal of Economics 97: 411-20.

Kennedy, Peter. 2008. A Guide to Econometrics. Malden, MA: Blackwell Publishing.

Kollins, Katharine, Bethany Speer, and Karlynn Cory. 2010. Solar PV Project Financing: Regulatory and Legislative Challenges for Third-Party PPA System Owners. Golden, CO: National Renewable Energy Laboratory.

Lacasa, I. D., and M. H. Shubbak. 2018. "Drifting Towards Innovation: The Co-Evolution of Patent Networks, Policy, and Institutions in China's Solar Photovoltaics Industry," Energy Research \& Social Science 38: 87-101.

Laincz, C. A. 2005. "Market Structure and Endogenous Productivity Growth: How do R\&D Subsidies Affect Market Structure?" Journal of Economic Dynamics \& Control 29: 187-223.

Litvak, Nicole. 2016. U.S. Residential Solar Financing 2016-2021. GTM Research. 


\section{—. 2017. U.S. Residential Solar Update 2017. GTM Research.}

Luthander, Rasmus, Joakim Widén, Daniel Nilsson, and Jenny Palm. 2015. PPhotovoltaic SelfConsumption in Buildings: A Review," Applied Energy 142.

Markusen, J. R., E. R. Morey, and N. D. Olewiler. 1993. "Environmental Policy When Market Structure and Plant Locations are Endogenous," Journal of Environmental Economics and Management 24: 69-86.

NC CETC. 2018. "Database of State Incentives for Renewables \& Efficiency." North Carolina Clean Energy Technology Center.

Nemet, Greg, Eric O'Shaughnessy, Ryan Wiser, Naim Darghouth, Galen Barbose, Ken Gillingham, and Varun Rai. 2017. "Characteristics of Low-Priced Solar PV Systems in the United States," Applied Energy 187: 501-13.

O'Shaughnessy, Eric. 2018a. The Effects of Market Concentration on Residential Solar PV Prices: Competition, Installer Scale, and Soft Costs. Golden, CO: National Renewable Energy Laboratory.

- 2018b. The Evolving Market Structure of the U.S. Residential Solar PV Installation Industry, 2000-2016. Golden, CO: National Renewable Energy Laboratory.

O'Shaughnessy, Eric, Greg Nemet, and Naïm Darghouth. 2018. "The Geography of Solar Energy in the United States: Market Definition, Industry Structure, and Choice in Solar PV Adoption," Energy Research and Social Science 38: 1-8.

Perea, Austin, Cory Honeyman, Shayle Kann, Allison Mond, MJ Shiao, Jade Jones, Scott Moskowitz, Ben Gallagher, Colin Smith, Shawn Rumery, Aaron Hom, Katie O'Brien, and Justin Baca. 2017. U.S. Solar Market Insight. GTM Research.

Pless, Jacquelyn, and Arthur van Benthem. 2017. The Surprising Pass-Through of Solar Subsidies. National Bureau of Economic Research.

Proudlove, Autumn, Brian Lips, David Sarkisian, and Achyut Shrestha. 2018a. 50 States of Solar: Q1 2018 Quarterly Report. NC Clean Energy Technology Center.

- 2018b. The 50 States of Solar: 2017 Policy Review. North Carolina Clean Energy Technology Center.

Quitzow, R. 2015. "Dynamics of a Policy-Driven Market: The Co-Evolution of Technological Innovation Systems for Solar Photovoltaics in China and Germany," Environmental Innovation and Societal Transitions 17: 126-48.

Sarzynski, A., J. Larrieu, and G. Shrimali. 2012. "The Impact of State Financial Incentives on Market Deployment of Solar Technology," Energy Policy 46: 550-57. 
Schmalensee, Richard, Vladimir Bulovic, Robert Armstrong, Carlos Batlle, Patrick Brown, John Deutch, Henry Jacoby, Robert Jaffe, Joel Jean, Raanan Miller, Francis O'Sullivan, John Parsons, Jose Ignacio Perez-Arriaga, Navid Seifkar, Robert Stoner, and Claudio Vergara. 2015. The Future of Solar Energy. Cambridge: MIT.

Sigrin, B., J. Pless, and E. Drury. 2015. "Diffusion into New Markets: Evolving Customer Segments in the Solar Photovoltaics Market," Environmental Research Letters 10.

Steward, Darlene, and Elizabeth Doris. 2012. The Effect of State Policy Suites on the Development of Solar Markets. Golden, CO: National Renewable Energy Laboratory.

Taylor, Mike, Joyce McLaren, Karlynn Cory, Ted Davidovich, John Sterling, and Miriam Makhyoun. 2015. Value of Solar: Program Design and Implementation Considerations. Golden, CO: National Renewable Energy Laboratory.

Tirole, Jean. 1988. The Theory of Industrial Organization. Cambridge, MA: The MIT Press.

Zhi, Q., H. H. Sun, Y. X. Li, Y. R. Xu, and J. Su. 2014. China's Solar Photovoltaic Policy: An Analysis Based on Policy Instruments," Applied Energy 129: 308-19. 


\section{Appendix}

This appendix provides detailed explanations and data sources for the calculation of the policy variables. It also describes the control variables used in the econometric model.

\section{Bill Savings}

Rate structure data are from the U.S. Utility Rate Database (URDB). ${ }^{7}$ Rate structures from the URDB were matched to customers in TTS based on the customer's utility service territory. Some residential customers pay tiered and time-of-use (TOU) rates. In a tiered rate, the customer pays different volumetric rates at different levels of electricity use. For tiered-rate customers, daily electricity use was estimated based on data from the U.S. Energy Information Administration's "Residential average monthly bill" data by state. ${ }^{8}$ It was assumed that typical PV customers use twice as much electricity as the average customer, given that PV customers tend to be aboveaverage electricity users (Darghouth, Barbose, and Wiser 2013). Based on estimated daily use, the percentage of the customer's daily use occurring below and above the tier was estimated, and an average electricity rate was calculated. In a TOU rate, customers pay different volumetric rates at different times of day. For TOU customers, the electricity rate is based on the average rate from 8 a.m. to 4 p.m., which corresponds roughly to peak PV output hours. Some utilities offer multiple residential rate structures. For TTS customers in these utility areas, there is unfortunately no way to determine which rate the customer pays. In these cases, an average rate structure was constructed across the multiple offers.

State- and utility-level net-metering requirements were based on information from DSIRE (NC CETC 2018). Archived DSIRE information was obtained for net-metering requirements from 2010 to 2013 for the states and utilities in this study. The net-metering requirements were confirmed as constant through 2016 for all states but Nevada, which moved from full retail rate net metering to $95 \%$ of retail rate in 2016 . Most states in the study required full retail rate net metering throughout the study period. Texas has no state-level net-metering requirements, though the utilities in the study provided net-metering credits at the utilities' avoided-cost rates throughout the study period. Similarly, New Hampshire moved from a full retail rate requirement to an avoided-cost requirement in 2012. In these cases, the avoided cost was assumed to equal the average wholesale electricity price (Taylor et al. 2015), based on wholesale price data from the EIA. ${ }^{9}$ In Massachusetts, export PV output must be compensated at "slightly less than the utility's full retail rate" (NC CETC 2018). Massachusetts net-metering credits were assumed to equal $95 \%$ of the full retail rate.

Using the rate structures and net-metering rates, lifetime electricity bill savings were estimated using the method described in Nemet et al. (2017). System output (kWh) was estimated based on insolation data from NREL's National Solar Radiation Database. ${ }^{10}$ The system is assumed to produce for 20 years and degrade at an annual rate of $0.5 \%$. Onsite use is assumed to consume $34 \%$ of output, with $66 \%$ of output being exported to the grid and compensated at the relevant net-metering rate, based on findings summarized in Luthander et al. (2015). Future savings were

\footnotetext{
7 “Utility Rate Database," OpenEI, https://openei.org/wiki/Utility_Rate_Database.

8 “Electric Sales, Revenue, and Average Price,” EIA, https://www.eia.gov/electricity/sales revenue price/.

9 "Wholesale Electricity and Natural Gas Market Data," EIA, https://www.eia.gov/electricity/wholesale/.

10 “National Solar Radiation Data Base,” NREL, https://rredc.nrel.gov/solar/old data/nsrdb/.
} 
discounted to a net present value (NPV) using a discount rate of 7\%. The NPV is then normalized by system size to produce a bill savings variable in terms of dollars per watt $(\$ / W)$.

\section{Subsidies}

Rebate data were based on data reported by PV incentive programs in the TTS data set. State ITC values were estimated based on information from DSIRE. These two upfront subsidies were summed, normalized by system size, and reported in terms of dollars per watt $(\$ / W)$.

\section{Ongoing Incentives}

Production-based incentives other than SRECs were based on data provided in TTS. Massachusetts and New Jersey are the only two states in this study with active SREC markets. SREC revenues in these states are based on the average value of SRECs over the study period (2010-2016): \$314/MWh and \$285/MWh in Massachusetts and New Jersey respectively. These rates were assumed to be accrued for the first 5 years. Beyond 5 years, customers in Massachusetts were assumed to earn $\$ 100 / \mathrm{MWh}$ for an additional 5 years, while customers in New Jersey were assumed to earn $\$ 100 /$ MWh for an additional 10 years, which is consistent with the approach applied in Nemet et al. (2017). This approach reduces future revenue assumptions to account for the effects of the volatility of SREC markets on customer expectations. The system is assumed to degrade at a rate of $0.5 \%$. Future savings were discounted using a discount rate of $7 \%$. The NPV is then normalized by system size to produce an ongoing incentives variable in terms of dollars per watt $(\$ / W)$.

\section{Interconnection Burden}

Interconnection burden is based on annual state-level scores compiled by Freeing The Grid (2018). It rates state-level interconnection requirements on a scale of $\mathrm{A}, \mathrm{B}, \mathrm{C}, \mathrm{D}$, and $\mathrm{F}$. The letter grades were converted to numeric burden scores, with a score of 1 corresponding to an A grade (least burden), a score of 2 corresponding to a $\mathrm{B}$, and a score of 3 corresponding to a $\mathrm{C}, \mathrm{D}$, or $\mathrm{F}$ grade (most burden). In some cases, markets span multiple states. Where a market falls in two states with different interconnection burden scores, the score was rounded according to the weighted average to treat the interconnection burden as a factor variable in the regression.

\section{TPO}

TPO penetration levels were calculated based on TTS.

\section{Control Variables}

Most of the controls are straightforward (Table A-1), with the exception of the entry pool variable. Dunne et al. (2013) use an entry pool variable as a proxy for the number of relatedservice firms in a market that could potentially enter a given industry. This variable may be particularly relevant in PV installation, given that many PV installers spin off from relatedservice industries such as electrical contracting and roofing, and about half of installers continue to offer related services (EnergySage 2018). Markets with many related-service firms have many potential PV entrants and could — all else being equal—yield less-concentrated PV markets. To control for these dynamics, the model includes an entry pool variable equal to the number 
of roofing and heating, ventilation, and air conditioning contractors in the market. Electrical contractors were excluded from the entry pool because PV installers are classified as electrical contractors in the U.S. census data.

Table A-1. Summary Statistics for Control Variables

\begin{tabular}{lrrrrc}
\hline Variable & Mean & SD $^{\mathbf{a}}$ & Min. & Max. & Source \\
\hline Sales tax $(\$ / \mathrm{W})$ & 0.07 & 0.09 & 0.00 & 0.31 & TTS \\
Number of systems installed in market & 153.13 & 436.08 & 1 & 11,773 & Calculated \\
Entry pool & $1,953.25$ & $6,321.07$ & 1 & 179,965 & Census \\
Labor cost index & 851.29 & 125.93 & 515.75 & $1,278.3$ & $\mathrm{BLS}^{\mathrm{b}}$ \\
Household density $\left(1,000\right.$ households $\left./ \mathrm{mi}^{2}\right)$ & 1.09 & 1.91 & 0.00 & 20.67 & Census \\
\% population high school to Bachelor's degree & 52.67 & 11.86 & 13.30 & 84.9 & Census \\
\% population > Bachelor's degree & 35.98 & 15.80 & 3.88 & 85.0 & Census \\
\% population income $\$ 25,00-\$ 50,000$ & 19.37 & 5.64 & 2.80 & 38.73 & Census \\
\% population income $\$ 50,000-\$ 100,000$ & 29.27 & 4.67 & 0.00 & 62.5 & Census \\
\% population income $>100 \mathrm{k}$ & 33.87 & 14.06 & 0.00 & 72.7 & Census \\
\hline
\end{tabular}

a Standard deviation; ${ }^{\text {b }}$ U.S. Bureau of Labor Statistics 